\title{
A Review of Dengue's Historical and Future Health Risk from a Changing Climate
}

\author{
Sutyajeet Soneja ${ }^{1} \cdot$ Gina Tsarouchi $^{2} \cdot$ Darren Lumbroso $^{2} \cdot$ Dao Khanh Tung $^{3}$
}

Accepted: 7 June 2021/ Published online: 16 July 2021

(C) The Author(s) 2021

\begin{abstract}
Purpose of review The purpose of this review is to summarize research articles that provide risk estimates for the historical and future impact that climate change has had upon dengue published from 2007 through 2019.

Recent findings Findings from 30 studies on historical health estimates, with the majority of the studies conducted in Asia, emphasized the importance of temperature, precipitation, and relative humidity, as well as lag effects, when trying to understand how climate change can impact the risk of contracting dengue. Furthermore, 35 studies presented findings on future health risk based upon climate projection scenarios, with a third of them showcasing global level estimates and findings across the articles emphasizing the need to understand risk at a localized level as the impacts from climate change will be experienced inequitably across different geographies in the future.

Summary Dengue is one of the most rapidly spreading viral diseases in the world, with $\sim 390$ million people infected worldwide annually. Several factors have contributed towards its proliferation, including climate change. Multiple studies have previously been conducted examining the relationship between dengue and climate change, both from a historical and a future risk perspective. We searched the U.S. National Institute of Environmental Health (NIEHS) Climate Change and Health Portal for literature (spanning January 2007 to September 2019) providing historical and future health risk estimates of contracting dengue infection in relation to climate variables worldwide. With an overview of the evidence of the historical and future health risk posed by dengue from climate change across different regions of the world, this review article enables the research and policy community to understand where the knowledge gaps are and what areas need to be addressed in order to implement localized adaptation measures to mitigate the health risks posed by future dengue infection.
\end{abstract}

Keywords Dengue $\cdot$ Climate change $\cdot$ Global health $\cdot$ Vector borne disease

\section{Introduction}

According to the World Health Organization, an estimated 390 million (range 284-528 million) people worldwide are infected with dengue annually, 96 million (range 67-136 million) of which present clinical manifestations [1-3]. People in more than 125 countries, encompassing over $50 \%$ of the

Gina Tsarouchi

G.Tsarouchi@hrwallingford.com

1 United Nations Development Programme, Vietnam Office, Washington, DC, USA

2 HR Wallingford, Howbery Park, Wallingford, Oxfordshire OX10 8BA, UK

3 United Nations Development Programme, Vietnam Office, 304 Kim Ma, Hanoi, Vietnam world's population, are potentially at risk of infection [4], with the main vectors for transmission to humans being the Aedes aegypti and Aedes albopictus mosquitoes [5-7]. Caused by four closely related dengue viral serotypes (DENV 1-4) of the genus Flavivirus, dengue infection clinically manifests itself in many ways ranging from acute febrile illness, nausea, vomiting, eye/muscle/joint/bone pain, rashes, life-threatening situations (e.g., hemorrhage, known as dengue hemorrhagic fever), and even death with a case fatality ranging from lower than 1 to $20 \%$ [5, 8-12]. Furthermore, the global total direct (medical care and travel) and indirect (lost time and productivity) cost of dengue illness has been estimated at $\$ 8.9$ billion (USD) annually [13]. Dengue is one of the most rapidly spreading viral diseases in the world, with the burden of disease having increased an estimated 30-fold over the last half century, despite increasing efforts to curb or reverse the upward trend [5, 14]. Many factors have contributed towards this 
spread including globalization, trade and shipping, shifts in demographics and urbanization patterns, inadequate domestic water supplies, and an increase of infected travelers acting as carriers over recent decades $[5,15,16]$. Weather or climate variables, such as temperature, humidity, high levels of precipitation, and vapor pressure have shown strong associations with altering the risk of contracting dengue $[1,8,17]$. Through multiple, interrelated mechanisms, climate variables can influence dengue transmission dynamics (e.g., by lengthening the dengue 'season' in endemic areas or stimulating the establishment of dengue in nascent areas), or even alter the temporal and spatial dynamics of dengue ecology (e.g., by increasing the mosquitoes flying range and shortening the incubation period) [8, 18-22]. Several studies have illustrated that climate change, via changes in temperature and precipitation, as well as increases in intensity, frequency, and duration of extreme weather events, has and will continue to impact the transmission of infectious diseases like dengue in many different parts of the world and especially in temperate regions [23-29].

Possessing an understanding of what epidemiological evidence currently exists on how climate change has historically impacted the risk of dengue infection, and how it may impact future risk, is important to understand so that future funding can be directed towards addressing knowledge gaps in order to better inform the development of localized health adaptation strategies. In this study, we synthesize recent literature assessing the historical and future health risk of dengue infections from climate change across all regions of the world.

\section{Methods}

From April to June 2020, we searched the U.S. National Institute of Environmental Health Sciences (NIEHS) Climate Change and Health Literature Portal [30], which maintains a database of literature related to climate change and health from January 2007 to September 2019. This date range represents the earliest allowable date and the most recent date that literature had been uploaded into the database, respectively. We utilized the keyword "dengue" and included studies published in English that provided epidemiological health risk estimates (e.g., relative risk or odds ratios) in relation to climate variables based upon historical dengue infection data or future climate projection scenarios, as well as changes in mosquito habitat, that specifically referenced changes to potential exposure for humans to dengue. Furthermore, we focused on health risk estimates that exposure to or contracting dengue instead of specific morbidity or mortality estimates given the multiple ways that dengue manifests itself as well as range of case fatality as previously mentioned. We excluded studies that were systematic or meta-analysis review articles, studies providing only information on model development (e.g., correlation coefficients), studies presenting risk across time periods (e.g., seasonality, El Niño-Southern Oscillation or ENSO) as a standalone but not quantitatively describing how these periods were changing as a result of climate change, studies providing a risk function only in graphic format with limited information on providing $95 \%$ confidence intervals (95\% CI), and commentaries (see Figure 1 for flow chart of literature search strategy).

Study data, health and climate information, and key findings were extracted from each relevant paper and subsequently organized by continent, then alphabetical name of country, and chronological order of publication date. Studies providing historical health risk estimates are presented in Table 1 and studies presenting health risk estimates based upon future climate projection scenarios are presented in Table 2. For Table 1, variables presented show information on dengue data utilized and timeframes covered for historical analysis, types of climate variables assessed, and an overview of findings that include type of health risk estimate, analysis method utilized, and a high-level summary of each study's finding. Table 2 is similarly structured, with variables indicating type and timing of climate projection scenario utilized, whether the study references changes to mosquito habitat or infection, and a qualitative one-word descriptor summarizing the findings of each study, indicating whether cases are expected to increase, decrease, proceed in a mixed direction, or remain unchanged according to the future projection scenario(s) used in the study. A quality assessment of each article was not undertaken due to the diverse nature of the reviewed material.

\section{Results}

A total of 654 studies (no duplicates) were initially retrieved for screening and assessed for possible inclusion. After exclusion of non-pertinent articles, 30 studies met the final inclusion criteria for providing historical dengue health risk estimates based upon changes in climate variables and 35 studies met the final inclusion criteria for providing future dengue health risk estimates based upon climate projection scenarios (Fig. 1). Most studies were excluded for their irrelevance, particularly around not providing specific health risk estimates or only focusing on model development.

\section{Historical Health Risk Assessment}

Nearly all of the 30 studies presenting risk estimates of health impact based upon historical data (see Fig.2) were from the Asian continent $(n=24)$, with Vietnam having the most studies from Asia $(n=6)$. Air temperature (presented in units of ${ }^{\circ} \mathrm{C}$ ), rainfall (in $\mathrm{mm}$ ), and humidity $(\%)$ were the key climate variables (see Fig. 3) used in almost all of the papers, with some papers also including variables such as windspeed ( $n=4)$, sunshine hours $(n=3)$, sea surface temperature $(n=3)$, atmospheric 
Fig. 1 Flow chart illustrating article selection process for conducting literature search

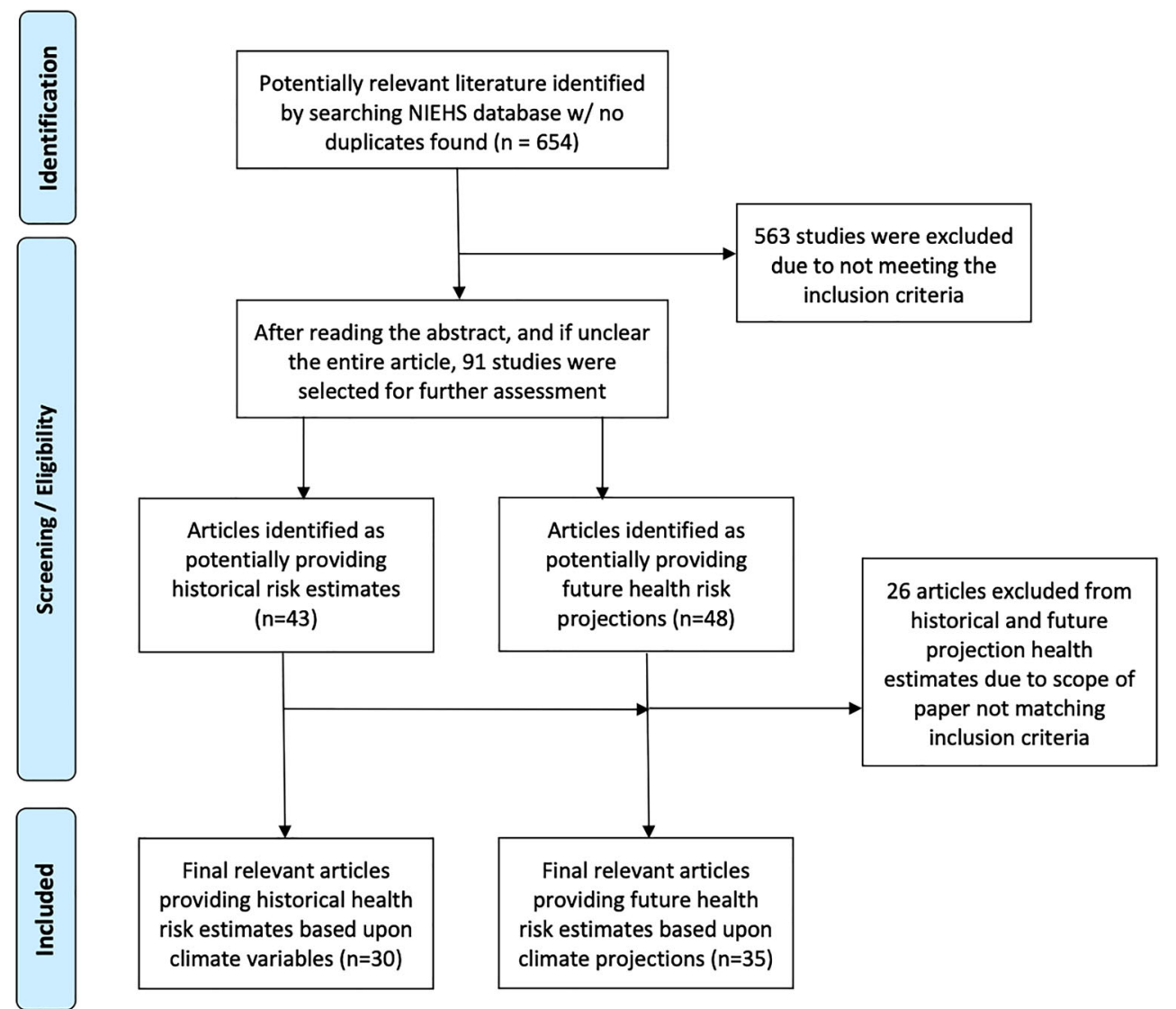

pressure $(n=2)$, dew point ( $n=2)$, and normalized difference vegetation index (NDVI, $n=1$ ). Statistical analysis involved dengue case data that ranged in length from 3 to 28 years on a frequency of daily, weekly, monthly, or annual aggregates that were either clinically diagnosed $(n=16)$ or laboratory confirmed ( $n=14)$. In addition, 18 of the papers included an assessment of lag effects (between climate conditions and dengue cases) that ranged from a few days up to eight months. The studies that were ascertained, based upon the search criteria, developed health risk estimates utilizing a variety of advanced statistical models that included generalized linear models, Poisson and logistic regression, and semiparametric techniques including generalized estimating equations, many of which integrated additional approaches that encompassed negative binomial, nonlinear, or quasi-methods and the incorporation of lag effects. Furthermore, one study by Anno et al. (2015) notably utilized spatial statistical analysis. A summary of significant risk estimates for each study is presented Supplementary information (please see S1: summary table of health risk estimates of dengue infection based upon climate variables).

For developing health risk estimates for contracting dengue based upon changes in temperature (see Table 1), all studies except one [31] included temperature as a part of their assessment. From the 29 studies that conducted health risk assessments as a function of temperature, 19 demonstrated increased risk, seven presented a mixture of increased risk or protective effects, one demonstrated only protective effects, and two studies showed no change in risk. Across the 19 studies showcasing increased risk of dengue infection, differing associations were determined. Highlights include varying increases in incidence of dengue found for every $1^{\circ} \mathrm{C}$ increase in temperature, from $61 \%$ in Australia [32], 12-22\% in Cambodia [33], $5 \%$ in Vietnam [34], 2.6\% in Mexico [35], and $0.7 \%$ in Timor-Leste [36]; In Sri Lanka and southern Taiwan, respectively, Liyanage et al. (2016) demonstrated that with increasing weekly average temperature the relative probability of dengue infections increased linearly [37], while Chien et al. (2014) illustrated that dengue risk increased with weekly minimum average temperature especially when accounting for lag effects from the 5 to 18 week range. Of the seven studies showing mixed effects, four studies demonstrated that lower temperatures had increasing risk while higher temperatures had protective effects [38-41]. The risk profile also changed based upon geographic location across almost all of the studies, with Vu et al. (2014) highlighting that even within a country (i.e., Vietnam) risk can increase or decrease based upon location.

For developing health risk estimates for contracting dengue based upon changes in precipitation (see Table 1), 27 of the 30 studies were found to include precipitation as part of their assessment. Of these, 16 studies demonstrated increased risk, 


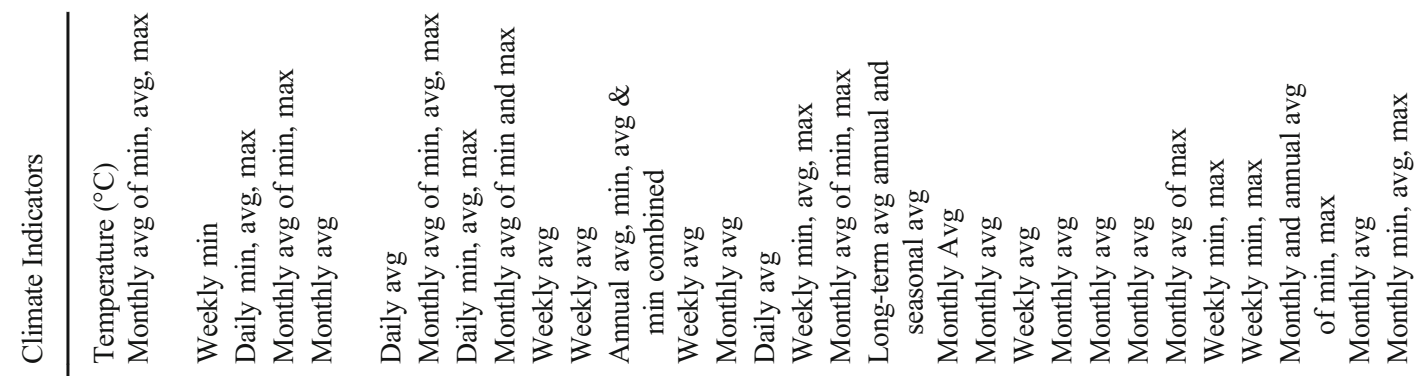

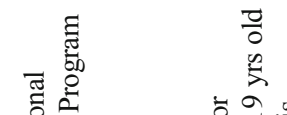

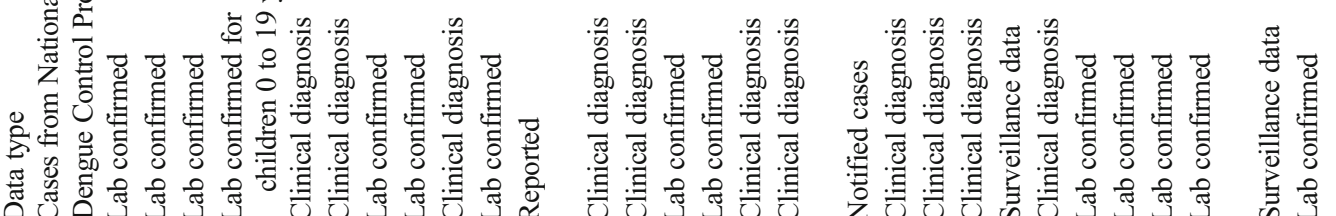
の

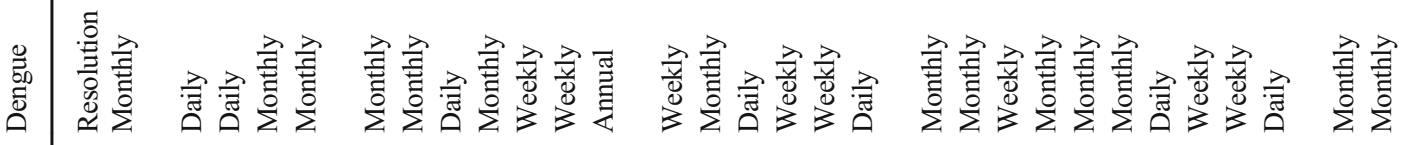

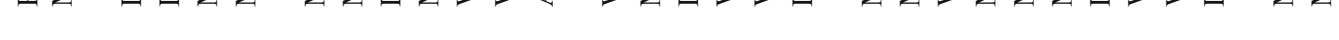
$\stackrel{\text { กิ }}{\stackrel{4}{5}}$

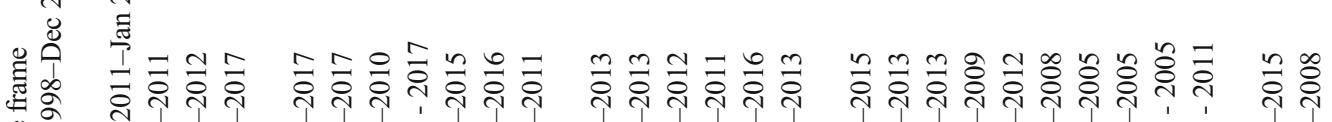

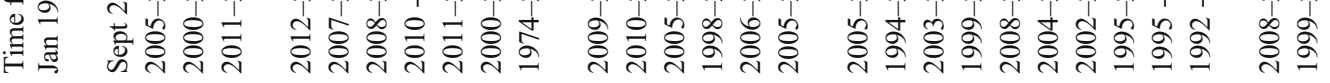

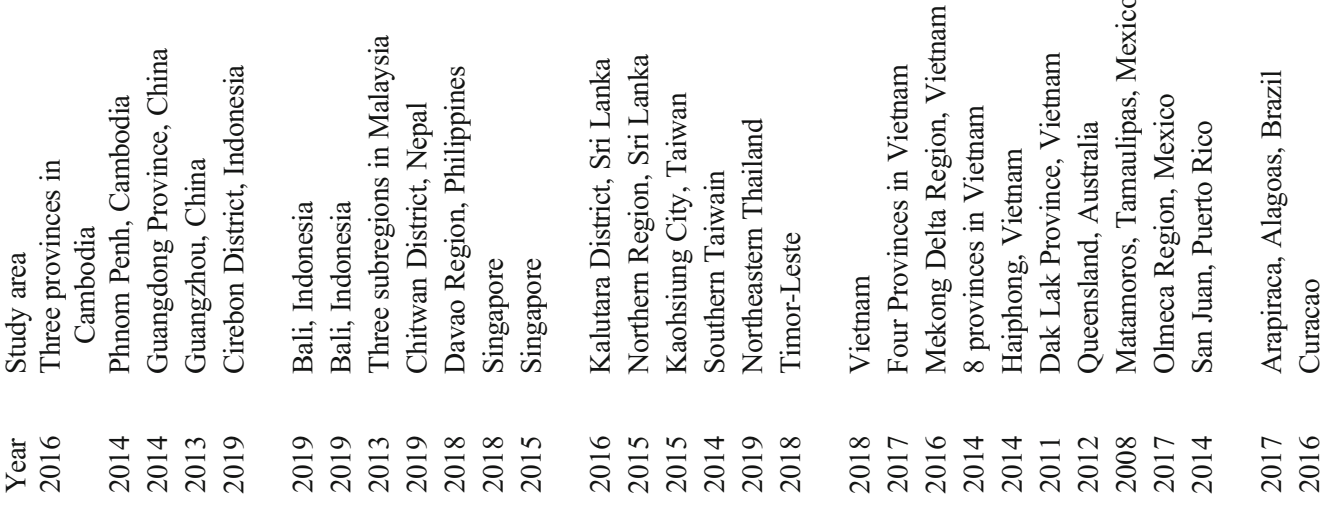

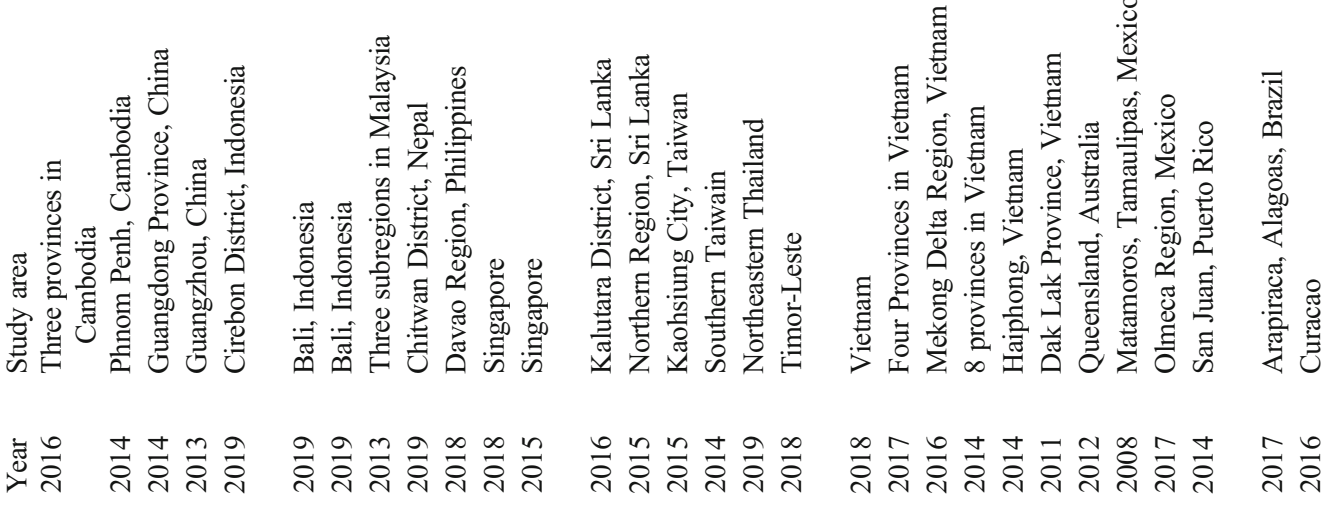

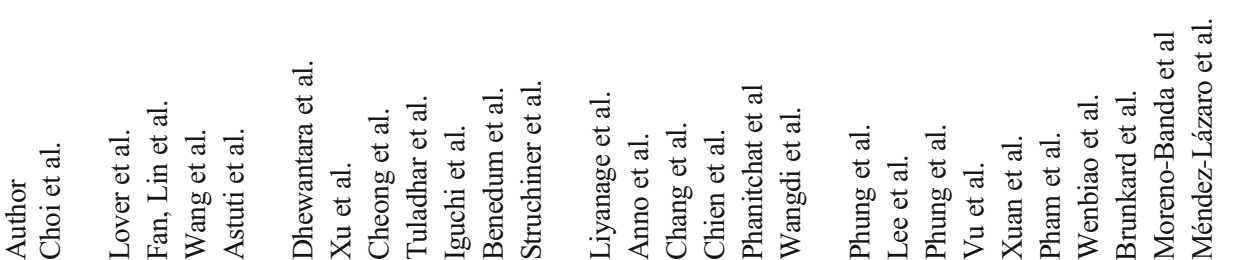

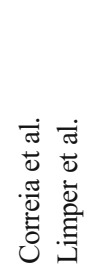

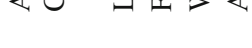

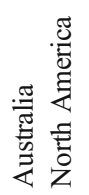

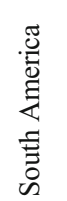

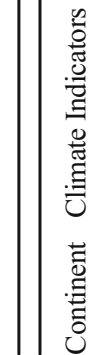




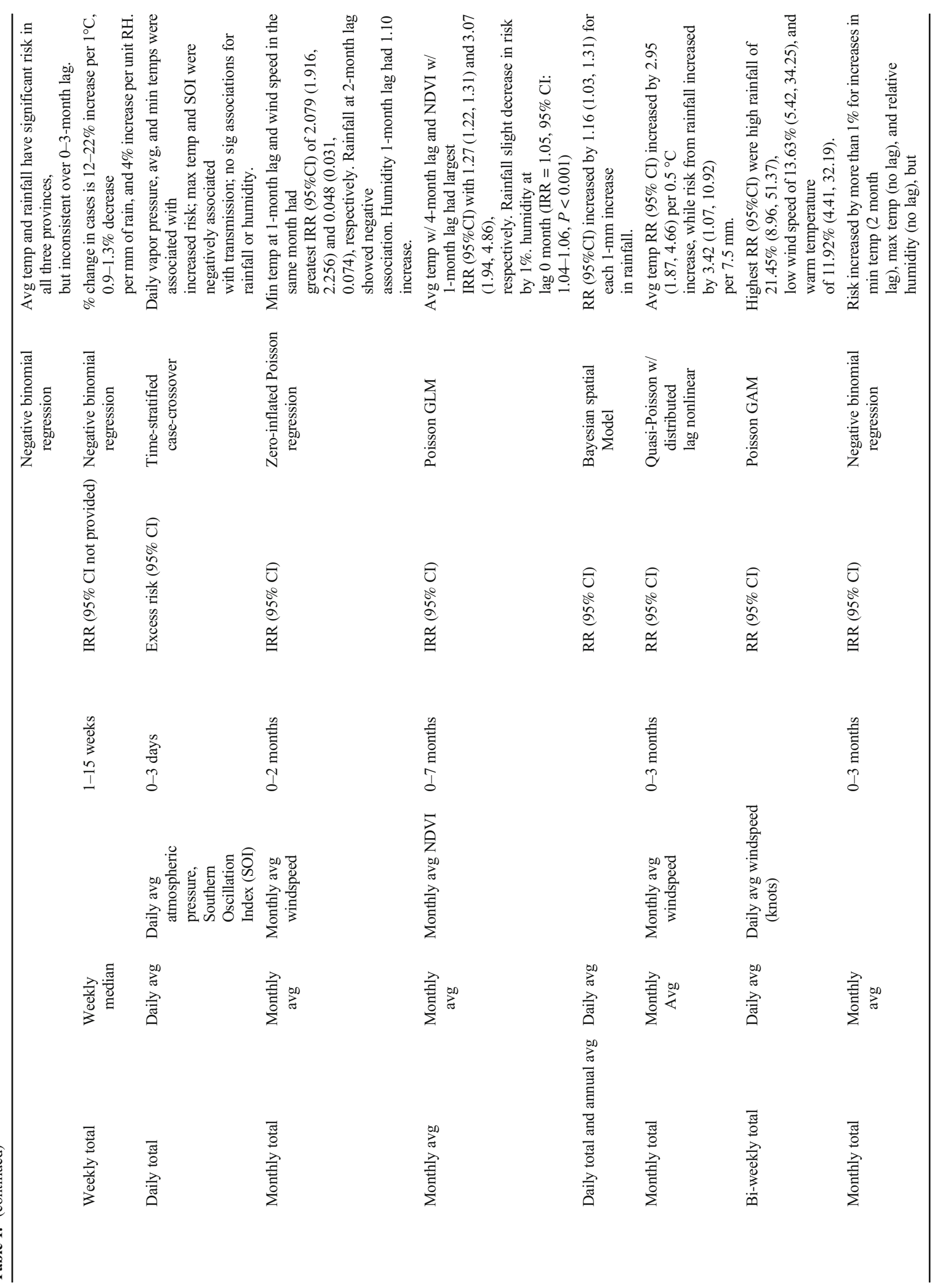




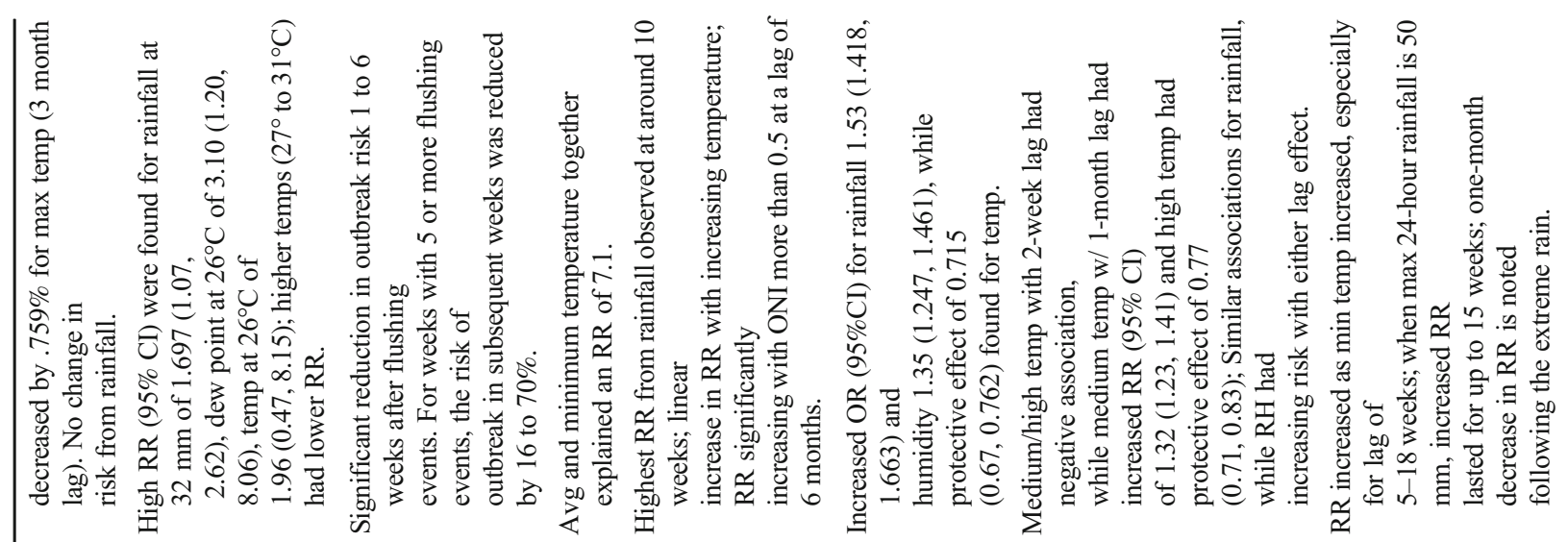
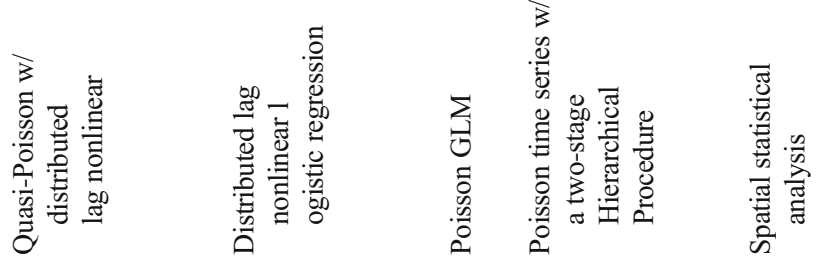

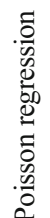
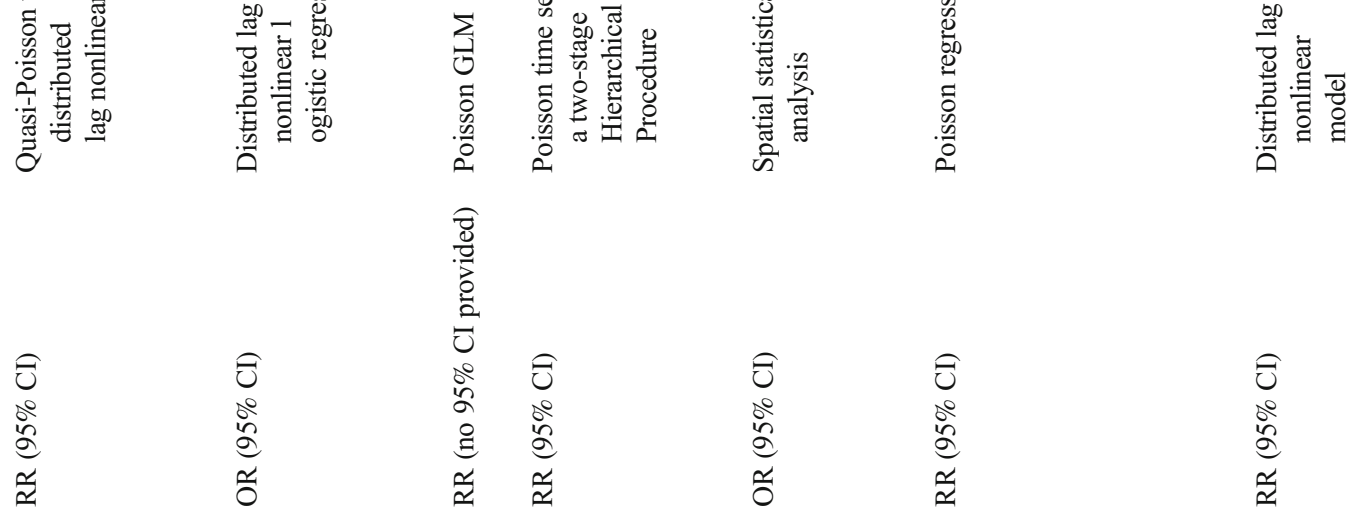

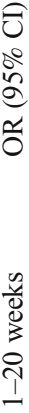

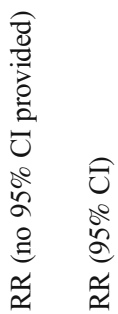

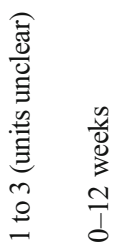

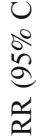

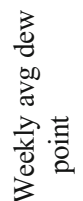

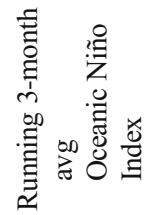

$\frac{\sqrt{3}}{3}$

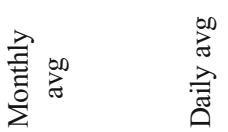

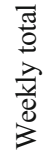

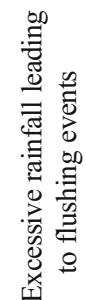

$\frac{7}{0}$
$\frac{0}{2}$
$\frac{2}{0}$
3
3

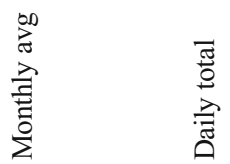

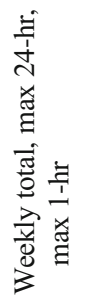




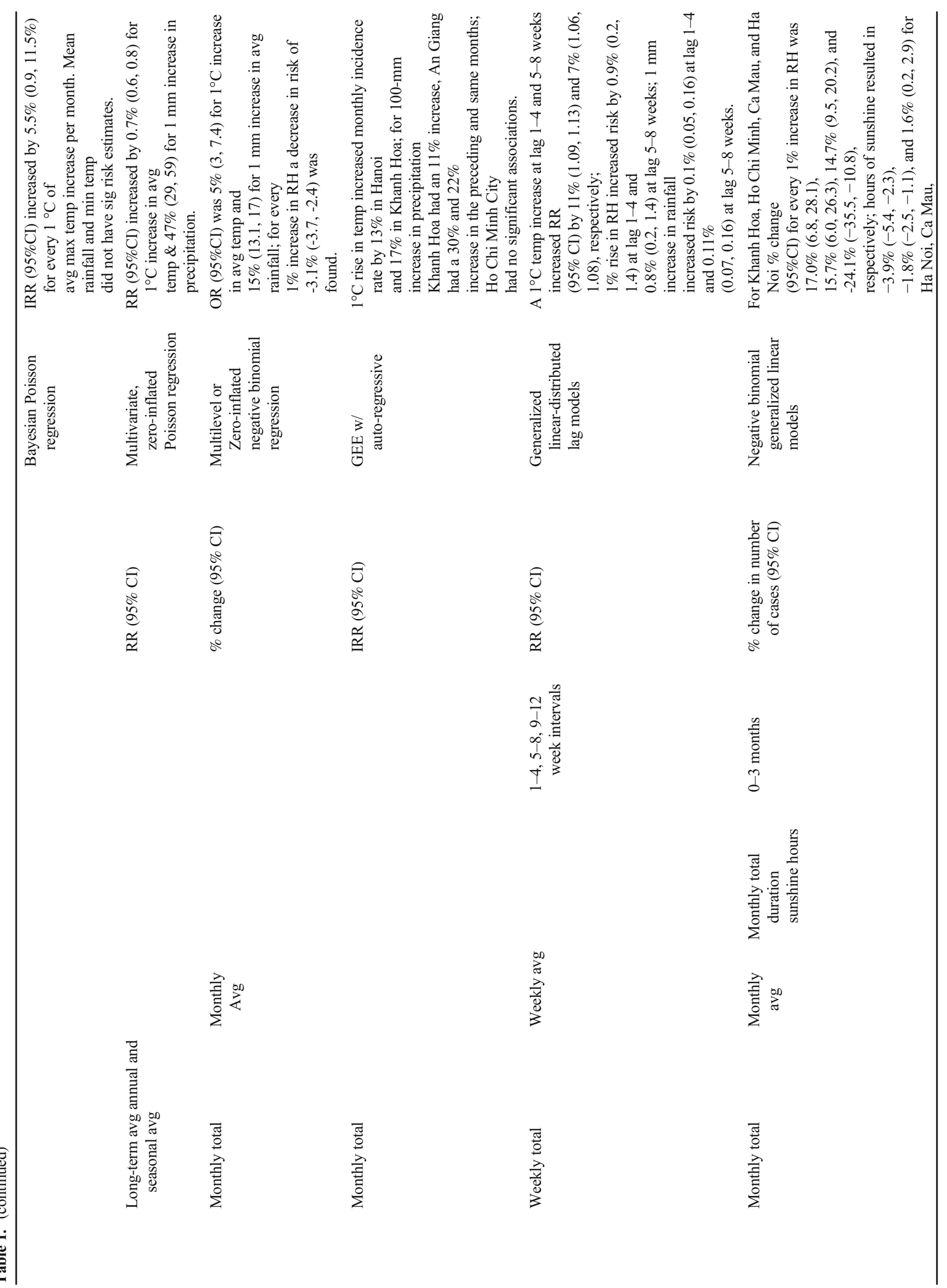




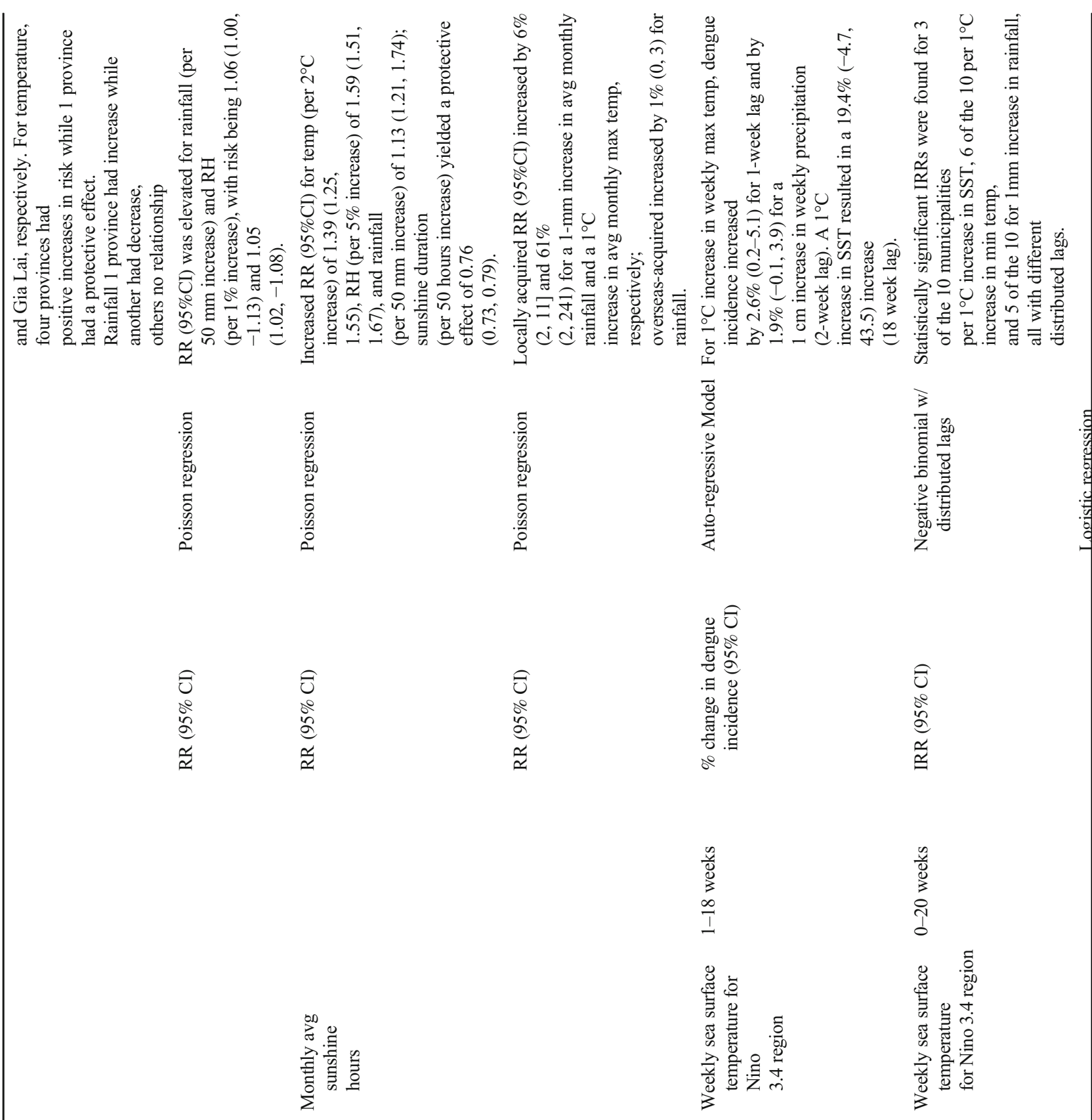

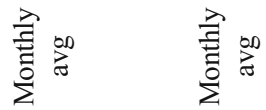

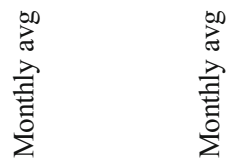

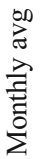

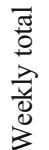

丞

爱

虽完 


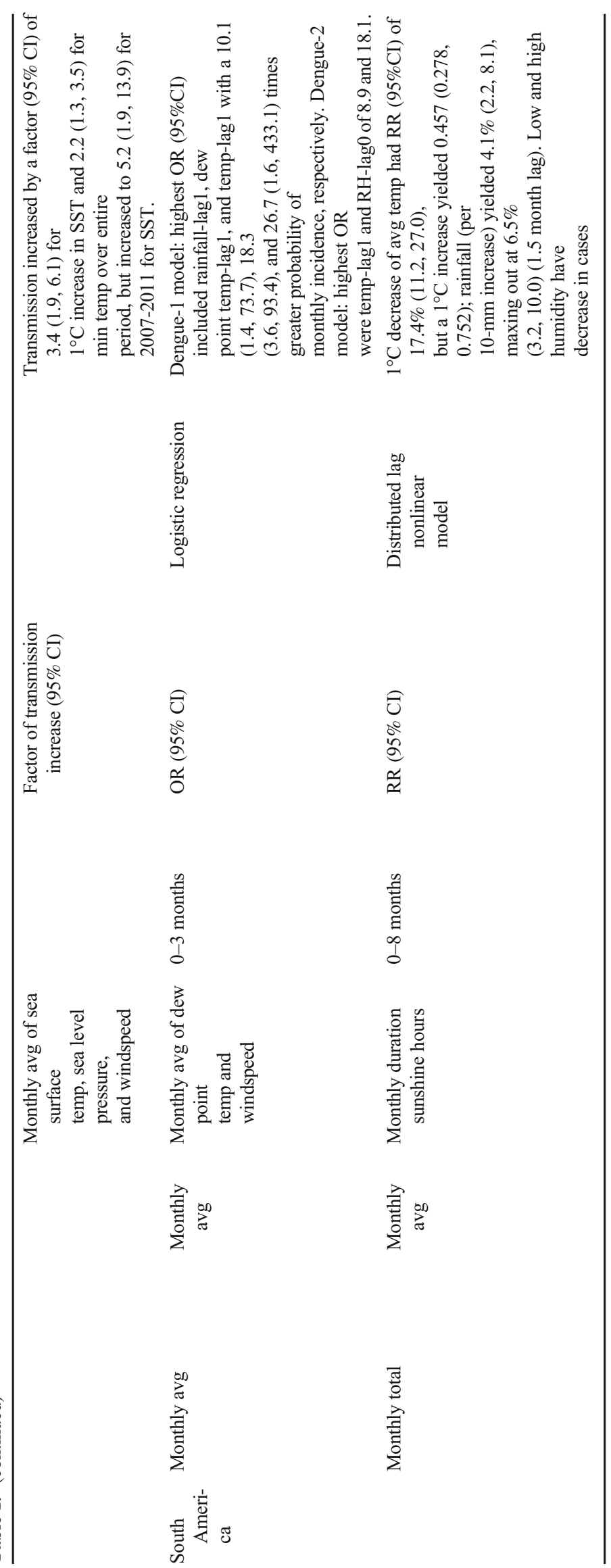


Table 2. Future risk of dengue infection based upon climate projection scenarios across different regions of the world.

\begin{tabular}{|c|c|c|c|c|c|c|c|c|}
\hline Continent & Author & $\begin{array}{l}\text { Publication } \\
\text { year }\end{array}$ & Location & $\begin{array}{l}\text { Habitat/ } \\
\text { infections }\end{array}$ & $\begin{array}{l}\text { Projection } \\
\text { time frame }\end{array}$ & $\begin{array}{l}\text { Climate scenario } \\
\text { utilized }\end{array}$ & Finding & $\begin{array}{l}\text { Projected } \\
\text { future } \\
\text { direction } \\
\text { of dengue }\end{array}$ \\
\hline Africa & Mweya et al & 2016 & Tanzania & Habitat & $\begin{array}{l}2020 \text { and } \\
2050\end{array}$ & CMIP5 & $\begin{array}{l}2020 \text { and } 2050 \text { climate } \\
\text { scenarios show risk } \\
\text { intensification in } \\
\text { dengue epidemic risk } \\
\text { areas with variations } \\
\text { across geography. }\end{array}$ & Increase \\
\hline \multirow[t]{7}{*}{ Asia } & Banu et al. & 2014 & Bangladesh & Infections & 2100 & $\begin{array}{l}\text { Assessed a } 1,2, \\
\text { and } 3.3^{\circ} \mathrm{C} \\
\text { increase in } \\
2100\end{array}$ & $\begin{array}{l}\text { If temperature increases } \\
\text { by } 3.3^{\circ} \mathrm{C} \text {, projected } \\
\text { increase of } 16,030 \\
\text { cases by } 2100 \text { in } \\
\text { Dhaka. }\end{array}$ & Increase \\
\hline & Fan et al. & 2019 & China & Infections & $\begin{array}{l}2020 \mathrm{~s}, \\
2030 \mathrm{~s} \text {, } \\
2050 \mathrm{~s} \text {, and } \\
2100 \mathrm{~s}\end{array}$ & $\begin{array}{l}\text { CMIP5 RCP 2.6, } \\
4.5,6.0 \text {, and } 8.5\end{array}$ & $\begin{array}{l}\text { For RCP } 8.5 \text { in } 2100 \mathrm{~s} \text {, the } \\
\text { population and } \\
\text { expanded high risk } \\
\text { areas would increase } \\
4.2 \text {-fold and } 2.9 \text {-fold. }\end{array}$ & Increase \\
\hline & Li et al. & 2017 & $\begin{array}{l}\text { City of } \\
\text { Guangzh- } \\
\text { ou, China }\end{array}$ & Infections & $2020-2070$ & $\begin{array}{l}\text { CMIP5 RCP 2.6, } \\
4.5,6.0 \text {, and } 8.5\end{array}$ & $\begin{array}{l}\text { Both RCP2.6 and } 8.5 \\
\text { have similar trends, } \\
\text { but scenario RCP8.5 } \\
\text { cases have overall } \\
\text { greater incidence. }\end{array}$ & Mixed \\
\hline & $\begin{array}{l}\text { Ministry of } \\
\text { Environment \& } \\
\text { Forests-Governm- } \\
\text { ent of India }\end{array}$ & 2012 & India & Infections & 2030 & $\begin{array}{l}\text { SRES A1B } \\
\text { (temperature } \\
\text { and } \\
\text { temperature+ } \\
\text { relative } \\
\text { humidity) }\end{array}$ & $\begin{array}{l}\text { In } 2030 \text {, increase in } \\
\text { transmission months } \\
\text { in northern areas and } \\
\text { reduction in western } \\
\text { part of southern India. }\end{array}$ & Mixed \\
\hline & Dhiman et al. & 2010 & India & Infections & 2050 & HadRM2 & $\begin{array}{l}\text { With } 4^{\circ} \mathrm{C} \text { temperature } \\
\text { rise, transmission may } \\
\text { be } 2 \text { to } 5 \text { times more } \\
\text { with new areas in } \\
\text { northern } \\
\text { sub-Himalayan region } \\
\text { and in southern most } \\
\text { areas. }\end{array}$ & Increase \\
\hline & Lee et al. & 2018 & Korea & Infections & 2070 & $\begin{array}{l}\text { CMIP5 RCP 2.6, } \\
4.5,6.0 \text {, and } 8.5\end{array}$ & $\begin{array}{l}\text { Epidemic duration } \\
\text { increases by more } \\
\text { than } 30 \text { days for RCP } \\
6.0 \text { and } 8.5 \text {. Vectoral } \\
\text { capacity intensity } \\
\text { increases more than } \\
\text { 2-fold for the RCP } 6.0 \\
\text { and } 8.5 \text {. }\end{array}$ & Increase \\
\hline & Sriprom et al. & 2010 & $\begin{array}{l}\text { Sakon } \\
\text { Nakhon } \\
\text { province } \\
\text { in } \\
\text { Thailand }\end{array}$ & Infections & 2090--2099 & SRES A1B & $\begin{array}{l}\text { Infection spreads from } 3 \\
\text { most populated } \\
\text { districts to less } \\
\text { populated, \& } \\
\text { transmission period } \\
\text { increases from } 5 \text { to } 9 \\
\text { months. }\end{array}$ & Increase \\
\hline \multirow[t]{2}{*}{ Australia } & Williams et al. & 2016 & $\begin{array}{l}\text { Queensland } \\
\text { cities }\end{array}$ & Infections & 2046-2064 & SRES A2 and B1 & $\begin{array}{l}\text { Decreased dengue } \\
\text { transmission predicted } \\
\text { under A2, whereas } \\
\text { some increases are } \\
\text { likely under B1. }\end{array}$ & Mixed \\
\hline & Williams et al. & 2014 & $\begin{array}{l}\text { City of } \\
\text { Cairns }\end{array}$ & Habitat & 2046-2065 & SRES A2 and B1 & $\begin{array}{l}\text { A. aegypti abundance is } \\
\text { predicted to increase } \\
\text { under B1, but } \\
\text { decrease under } \mathrm{A} 2 \text {. }\end{array}$ & Mixed \\
\hline
\end{tabular}


Table 2. (continued)

\begin{tabular}{|c|c|c|c|c|c|c|c|c|}
\hline Continent & Author & $\begin{array}{l}\text { Publication } \\
\text { year }\end{array}$ & Location & $\begin{array}{l}\text { Habitat/ } \\
\text { infections }\end{array}$ & $\begin{array}{l}\text { Projection } \\
\text { time frame }\end{array}$ & $\begin{array}{l}\text { Climate scenario } \\
\text { utilized }\end{array}$ & Finding & $\begin{array}{l}\text { Projected } \\
\text { future } \\
\text { direction } \\
\text { of dengue }\end{array}$ \\
\hline & Newth et al. & 2010 & $\begin{array}{l}\text { All of } \\
\text { Australia }\end{array}$ & Infections & 2030 & SRES A1B & $\begin{array}{l}\text { Projected cost and } \\
\text { DALYs decrease } \\
\text { under both mitigation } \\
\text { response scenarios } \\
\text { that are given across } \\
\text { multiple R0 scenarios. }\end{array}$ & Decrease \\
\hline & Bambrick et at. & 2009 & $\begin{array}{l}\text { All of } \\
\text { Australia }\end{array}$ & Infections & $\begin{array}{l}2020,2050, \\
2070, \text { and } \\
2100\end{array}$ & $\begin{array}{l}\text { Four climate } \\
\text { scenarios } \\
\text { produced by } \\
\text { Australia's } \\
\text { Commonwealth } \\
\text { Scientific and } \\
\text { Industrial } \\
\text { Research } \\
\text { Organization }\end{array}$ & $\begin{array}{l}\text { Under 'no emissions } \\
\text { action,' there is an } \\
\text { increase in geographic } \\
\text { spread. Under } \\
\text { emissions mitigation, } \\
\text { transmission-suitable } \\
\text { areas remain limited } \\
\text { to northern } \\
\text { Queensland and to } \\
\text { Darwin. }\end{array}$ & Increase \\
\hline & Kearney et al. & 2009 & $\begin{array}{l}\text { Northern } \\
\text { Territory }\end{array}$ & Habitat & $\begin{array}{l}2010 \text { and } \\
2050\end{array}$ & SRES B1 & $\begin{array}{l}\text { Increased habitat } \\
\text { suitability throughout } \\
\text { much of Australia; } \\
\text { changed water storage } \\
\text { practices in response } \\
\text { to drought may have } \\
\text { greater effect. }\end{array}$ & Increase \\
\hline & Teurlai et al. & 2015 & $\begin{array}{l}\text { New } \\
\quad \text { Caledonia }\end{array}$ & Infections & 2100 & $\begin{array}{l}\text { CMIP5 RCP } 4.5 \\
\text { and } 8.5\end{array}$ & $\begin{array}{l}\text { Mean incidence rates } \\
\text { during epidemics } \\
\text { could double if temp } \\
\text { rises by } 3^{\circ} \mathrm{C} \text { by } 2100 .\end{array}$ & Increase \\
\hline \multirow[t]{4}{*}{ Europe } & Liu-Helmersson et al. & 2019 & $\begin{array}{l}\text { Entire } \\
\quad \text { continent } \\
\text { and } \\
10 \text {-city } \\
\text { focus }\end{array}$ & Habitat & $\begin{array}{l}2051-2060 \\
\text { and } \\
2091-209- \\
9\end{array}$ & $\begin{array}{l}\text { CMIP5 RCP2.6 } \\
\text { and } 8.5\end{array}$ & $\begin{array}{l}\text { For RCP2.6, minimal } \\
\text { change to current } \\
\text { situation throughout } \\
21 \text { st century, while } \\
\text { under RCP } 8.5 \text { large } \\
\text { parts of southern } \\
\text { Europe risks being } \\
\text { invaded by A. aegypti. }\end{array}$ & Increase \\
\hline & Liu-Helmersson et al. & 2016 & All of Europe & Infections & 2070-2099 & $\begin{array}{l}\text { CMIP5 RCP 2.6, } \\
4.5,6.0 \text {, and } 8.5\end{array}$ & $\begin{array}{l}\text { By century end, } \\
\text { A. aegypti could } \\
\text { expand to Northern } \\
\text { Europe under } \\
\text { RCP8.5. Ae. } \\
\text { albopictus could } \\
\text { expand to all of } \\
\text { Central Europe under } \\
\text { RCP8.5; however, } \\
\text { would remain the } \\
\text { same under RCP2.6. }\end{array}$ & Increase \\
\hline & Bouzid et al. & 2014 & All of Europe & Infections & $\begin{array}{l}2011-2040, \\
2041-207- \\
0, \text { and } \\
2071-210- \\
0\end{array}$ & SRES A1B & $\begin{array}{l}\text { Increase in risk } \\
\text { projected, with } \\
\text { highest incidence rates } \\
\text { found for the } \\
\text { long-term scenario } \\
\text { 2070-2100, with } \\
\text { substantial impact for } \\
\text { southern Europe. }\end{array}$ & Increase \\
\hline & Thomas et al. & 2011 & All of Europe & Habitat & $\begin{array}{l}2011-2040, \\
2041-207- \\
0, \text { and } \\
2071-210- \\
0\end{array}$ & $\begin{array}{l}\text { SRES A1B and } \\
\text { B1 }\end{array}$ & $\begin{array}{l}\text { Larger parts of the } \\
\text { Mediterranean will be } \\
\text { at risk. Even some } \\
\text { parts of Central } \\
\text { Europe (e.g., }\end{array}$ & Increase \\
\hline
\end{tabular}


Table 2. (continued)

\begin{tabular}{lllllll}
\hline Continent Author & $\begin{array}{l}\text { Publication } \\
\text { year }\end{array}$ & Location & $\begin{array}{l}\text { Habitat/ Projection } \\
\text { infections time frame }\end{array}$ & $\begin{array}{l}\text { Climate scenario } \\
\text { utilized }\end{array}$ & $\begin{array}{l}\text { Finding } \\
\text { future } \\
\text { direction } \\
\text { of dengue }\end{array}$ \\
\hline
\end{tabular}

\begin{tabular}{|c|c|c|c|c|c|c|c|c|}
\hline \multirow[t]{4}{*}{$\begin{array}{l}\text { North } \\
\text { America }\end{array}$} & Ogden et al. & 2014 & $\begin{array}{l}\text { US and } \\
\text { Canada }\end{array}$ & Habitat & $\begin{array}{l}2020 \text { s } \\
(2011-20- \\
40) \text { and } \\
2050 \text { s } \\
(2041-20- \\
70)\end{array}$ & $\begin{array}{l}\text { CMIP5 RCP } 4.5 \\
\text { and } 8.5\end{array}$ & $\begin{array}{l}\text { Modest future northward } \\
\text { range expansion of } \\
\text { A. albopictus by the } \\
\text { 2050s, but greater } \\
\text { range expansion, } \\
\text { particularly in eastern } \\
\text { and central Canada. }\end{array}$ & Increase \\
\hline & Butterworth et al. & 2017 & $\begin{array}{l}\text { Southeastern } \\
\text { USA }\end{array}$ & Infections & $2045-2065$ & SRES A1B & $\begin{array}{l}\text { Mosquito season length } \\
\text { in many locations may } \\
\text { increase, however } \\
\text { projected increases in } \\
\text { dengue transmission } \\
\text { are limited to the } \\
\text { southernmost US } \\
\text { locations. }\end{array}$ & Increase \\
\hline & Erickson et al. & 2012 & $\begin{array}{l}3 \text { cities in } \\
\text { USA }\end{array}$ & Habitat & $\begin{array}{l}2035-2065 \\
\quad \text { and } \\
2069-209- \\
9\end{array}$ & $\begin{array}{l}\text { SRES A1FI and } \\
\text { B1 }\end{array}$ & $\begin{array}{l}\text { Projected warming } \\
\text { shortened mosquito } \\
\text { lifespan, which in turn } \\
\text { decreased potential } \\
\text { dengue season. }\end{array}$ & Decrease \\
\hline & Kolivras et al. & 2010 & $\begin{array}{l}\text { State of } \\
\text { Hawaii, } \\
\text { USA }\end{array}$ & Habitat & 2025-2034 & HadCM2 & $\begin{array}{l}\text { Climate scenarios predict } \\
\text { expansion of } \\
\text { mosquito habitat and } \\
\text { potential dengue risk } \\
\text { areas; population at } \\
\text { risk projected to go } \\
\text { from } 532,036 \text { to } \\
1,181,770 \text {. }\end{array}$ & Increase \\
\hline \multirow[t]{3}{*}{$\begin{array}{l}\text { South } \\
\text { America }\end{array}$} & Cardoso-Leite et al. & 2014 & Brazil & Habitat & 2050 & SRES A2a & $\begin{array}{l}\text { Area covered by the } \\
\text { vector distribution in } \\
\text { Brazil will decrease in } \\
\text { future projections in } \\
\text { the north, but will } \\
\text { spread to the south. }\end{array}$ & Mixed \\
\hline & Escobar et al. & 2016 & Ecuador & Habitat & $\begin{array}{r}2030,2050 \\
\text { and } 2100\end{array}$ & SRES A2 & $\begin{array}{l}\text { A. aegypti potential area } \\
\text { of distribution } \\
\text { reduced by } 69 \%, \\
43 \% \text {, and } 48 \% \text { and } \\
\text { population at risk by } \\
84 \%, 47 \% \text {, and } 40 \% \\
\text { by } 2030,2050, \text { and } \\
2100, \text { respectively. } \\
\text { For } A \text {. albopictus, the } \\
\text { potential area of } \\
\text { distribution reduced } \\
\text { by } 45 \%, 35 \%, \text { and } \\
53 \% \text { and the number } \\
\text { of people potentially } \\
\text { exposed by } 58 \%, \\
46 \%, \text { and } 52 \% \text { in } \\
2030,2050, \text { and } 2100, \\
\text { respectively. }\end{array}$ & Decrease \\
\hline & $\begin{array}{l}\text { Colon-Gonzalez } \\
\text { et al. }\end{array}$ & 2018 & $\begin{array}{l}\text { Latin } \\
\text { America }\end{array}$ & Infections & $\begin{array}{c}2050 \text { and } \\
2100\end{array}$ & $\begin{array}{l}\text { SSP2 for three } \\
\text { different global } \\
\text { temperature }\end{array}$ & $\begin{array}{l}\text { Number of dengue cases } \\
\text { for the } 2050 \text { s period } \\
\text { was } 260 \% \text { larger with }\end{array}$ & Increase \\
\hline
\end{tabular}

Southwest Germany) can no longer be excluded at century end.

range expansion of A. albopictus by the 2050s, but greater particularly in eastern

in many locations may ease, however dengue transmission jected warming expansion of mosquito habitat and potential dengue risk as; population at vector distribution in of distribution reduced by $69 \%$, $84 \%, 47 \%$, and $40 \%$ by 2030,2050 , and 100 , respectively. or A. albopictus, the by $45 \%, 35 \%$, and $53 \%$ and the number people potentially 2030, 2050, and 2100 ,

different global for the 2050s period temperature 
Table 2. (continued)

\begin{tabular}{lllllll}
\hline Continent & Author & $\begin{array}{l}\text { Publication } \\
\text { year }\end{array}$ & Location & $\begin{array}{l}\text { Habitat/ Projection } \\
\text { infections time frame }\end{array}$ & $\begin{array}{l}\text { Climate scenario } \\
\text { utilized }\end{array}$ & $\begin{array}{l}\text { Finding } \\
\begin{array}{l}\text { Projected } \\
\text { direction } \\
\text { of dengue }\end{array}\end{array}$ \\
\hline
\end{tabular}

Worldwide Ryan et al.

Messina et al.

2019

Global

Infections 2020, 2050,

and 2080 change

scenarios $\begin{array}{cc}\text { scenarios } & \text { cases per year. } \\ \text { CMIP5 RCP 2.6, Nearly a billion people }\end{array}$ $4.5,6.0$, and 8.5 could face their first
CMIP5 RCP 4.5

SSP1, RCP 6.0

SSP2, and RCP 8.5 SSP3
Campbell et al.

2015
Global

Habita

2050
SRES A1B, A2, and $\mathrm{B} 1$ about 6.9 million extra exposure in the worst-case scenario, mainly in Europe and high-elevation tropical and subtropical regions.

Do not predict significant spread of dengue risk across continental Europe, with total area at risk increasing from $0.22 \%$ in 2015 to $0.62 \%$ in 2080 , with any expansions in population at risk highly uncertain. Globally, 2.25 billion more people will be at risk of dengue in 2080 compared to 2015 , bringing the total population at risk to over 6.1 billion, or $60 \%$ of the world's population.

A. aegypti predictions indicate potential for northward expansion in eastern North America, South Asia and East Asia, and southward in Africa and Australia; broadening distributional potential indicated in interior South America and Central Africa. A. albopictus, predictions gave clearer indications of expanding distributional potential in eastern North America and East Asia, plus expanding potential across Africa and in eastern and southern South America; distributional potential in Australia was anticipated to expand rather markedly for 
Table 2. (continued)

\begin{tabular}{llllll}
\hline Continent Author & $\begin{array}{l}\text { Publication } \\
\text { year }\end{array}$ & Location & $\begin{array}{l}\text { Habitat/ Projection } \\
\text { infections time frame }\end{array}$ & $\begin{array}{l}\text { Climate scenario } \\
\text { utilized }\end{array}$ & $\begin{array}{l}\text { Finding } \\
\text { future } \\
\text { direction } \\
\text { of dengue }\end{array}$
\end{tabular}

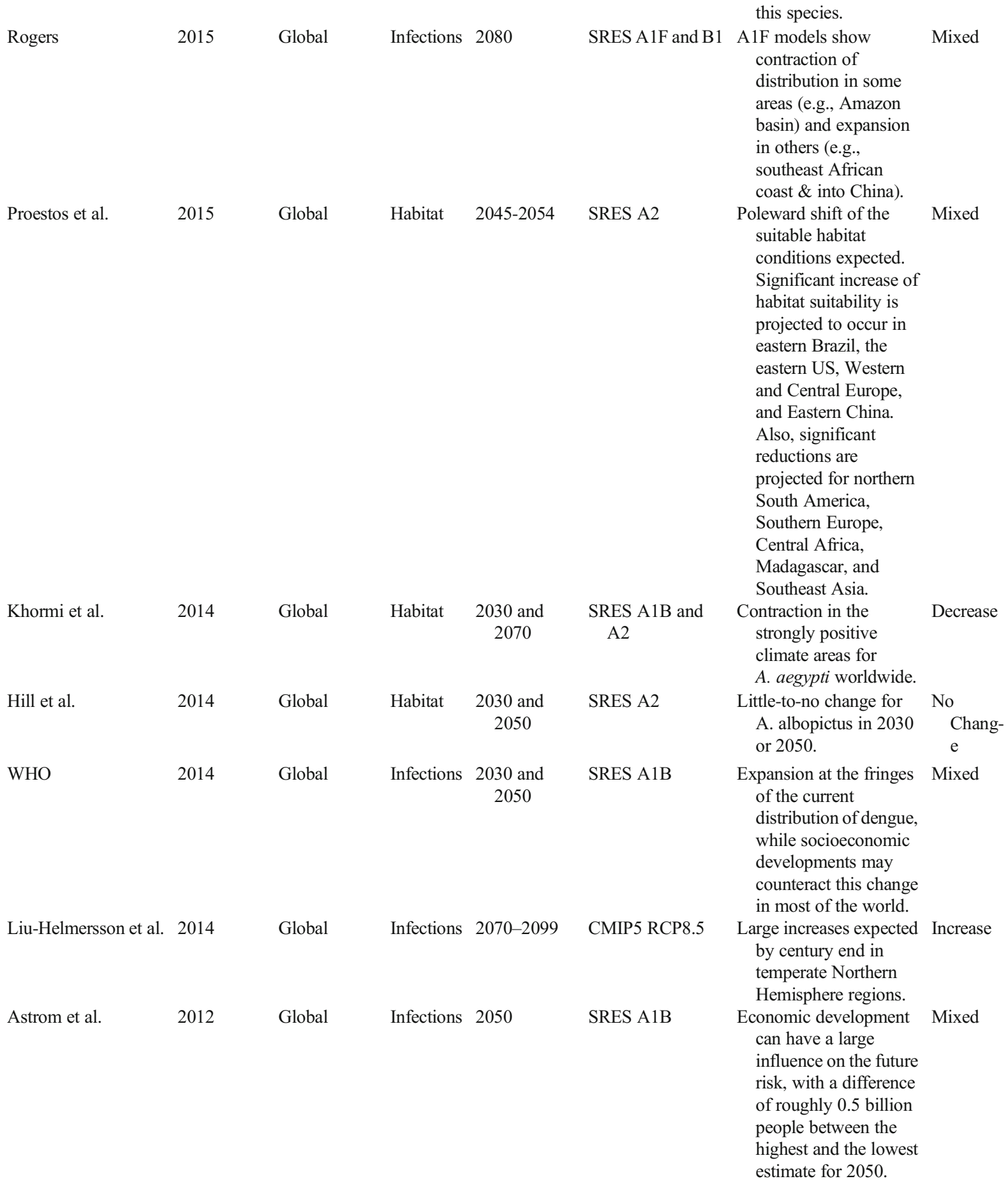

five presented a mixture of increased risk as well as protective effects, four demonstrated only protective effects, and three indicated no change in risk. For changes in rainfall, a range of increasing associations of contracting dengue were found 


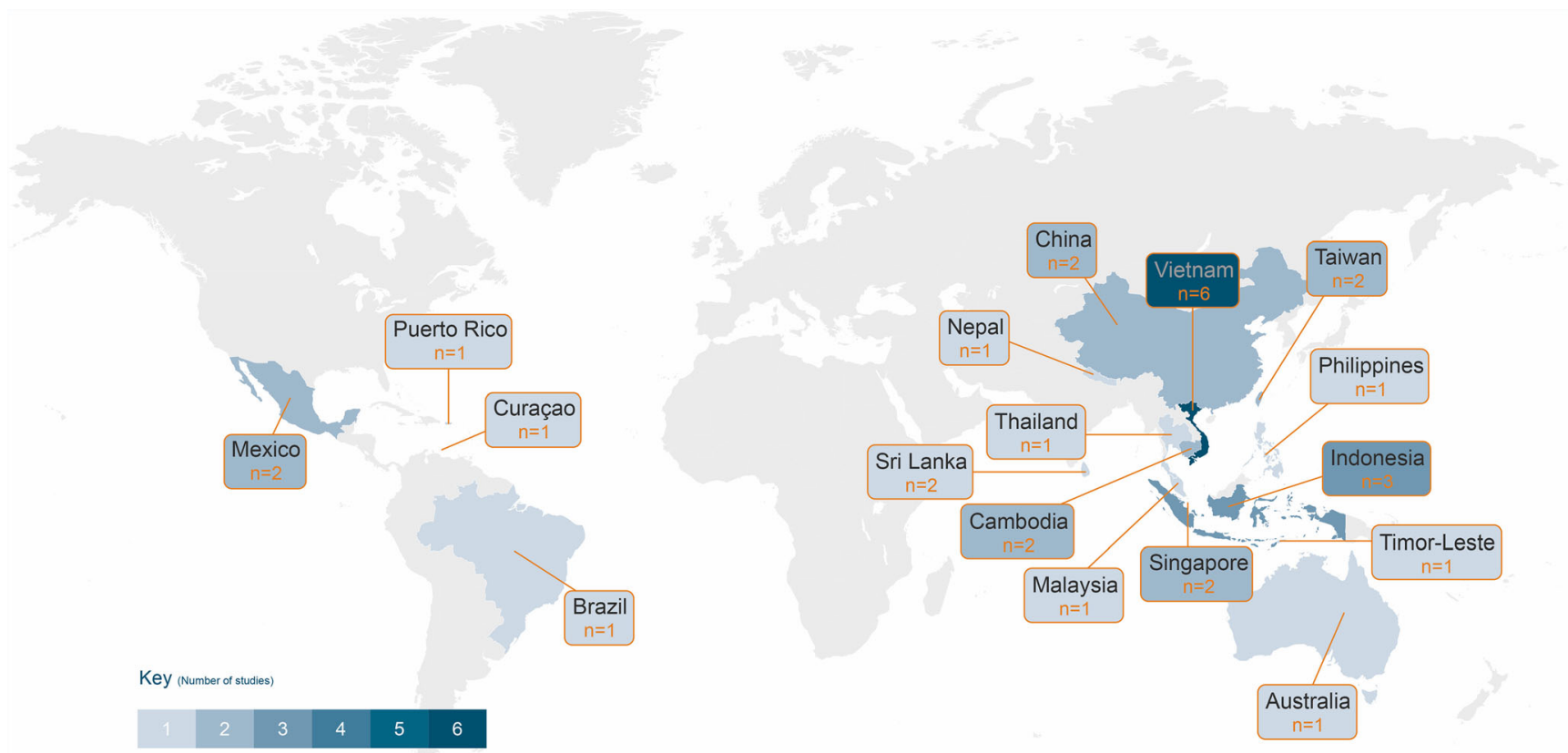

Fig. 2 Number of studies assessing historical dengue risk by country

including a $47 \%$ increase in dengue incidence (per $1 \mathrm{~mm}$ increase of rainfall calculated as a seasonal average) in TimorLeste [36], 5\% increase in dengue incidence (per $1 \mathrm{~mm}$ increase of rainfall calculated as a monthly total) in Vietnam [34], and 6\% increase (per $1 \mathrm{~mm}$ increase of rainfall calculated as a monthly average) in Australia [32]. Multiple studies have shown an increase of chance for contracting dengue with an increase in rainfall in some areas, but no relationships in others depending on geographic location or lag effect utilized [42-46]. Studies have also found a reduction in dengue risk from increasing rainfall. For example, a $0.9-1.3 \%$ reduction of dengue cases was found per weekly cumulative $\mathrm{mm}$ increase

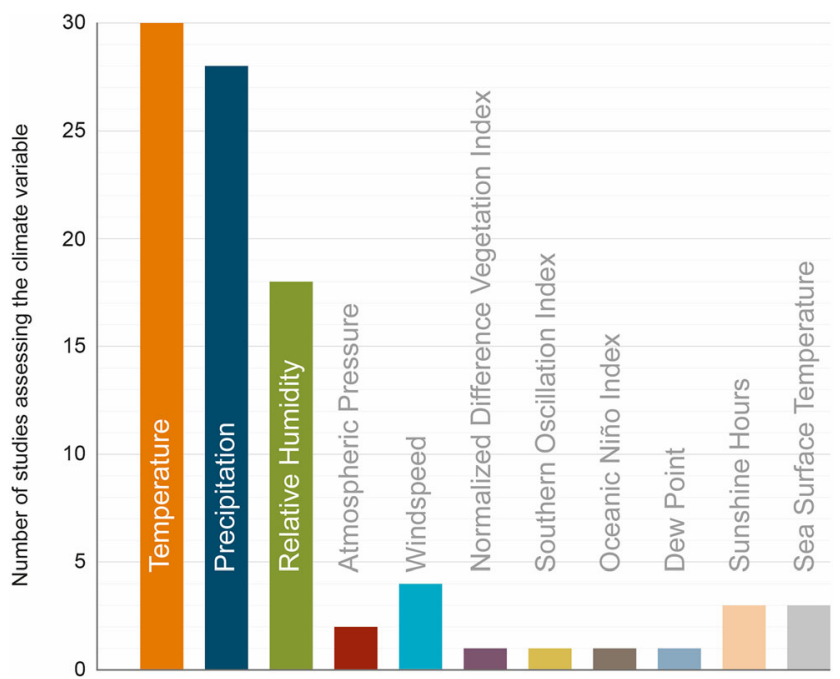

Fig. 3 Number of studies assessing the number of dengue cases by climate variable in rainfall in Cambodia [33], a 1\% risk reduction per monthly average $\mathrm{mm}$ increase in Indonesia [47], and significant reductions in the chance of an outbreak were found due to excessive rain considered to 'flush' out mosquito habitats in Singapore [31].

For developing risk estimates of contracting dengue based upon changes in relative humidity, 13 studies were identified. Of these, nine demonstrated increased risk, two studies were found to have a mixture of increased risk as well as protective effects, one study revealed only protective effects, and one study found no association. For a one-unit increase in humidity, a range of increased risk for contracting dengue was found (see Table 1), including increased risk of $4 \%$ in Cambodia [33], $10 \%$ in China [48], 35\% in Sri Lanka [49], and 5\% in Vietnam [50]. Additional interesting findings included relative humidity in Curaçao to have a protective effect at either lower or very high levels [51] and changes in the risk profile to be dependent upon geographic location (similar to temperature) even within a country (i.e., Vietnam) [42].

Findings from studies emphasized the importance of temperature, precipitation, and relative humidity, as well as lag effects, when trying to understand how climate change can impact the probability of contracting dengue. Furthermore, studies also emphasized the importance of analyses at a localized level as geographic location can be an important factor in terms of how changes in climate variables can be experienced. This review highlights areas of the world where evidence has been generated and significant areas where risk profiles remain to be developed, particularly for the African continent where no relevant studies were found. 


\section{Future Health Risk Assessment}

Of the 35 studies providing health-related risk estimates for contracting dengue based upon future climate projection scenarios extending as far out as the year 2100, 20 studies indicated an increase in future potential for dengue infection, while the others indicated a mixed direction $(n=11)$, decrease $(n=3)$, or no change $(n=1)$ for future dengue infections (see Fig. 4). The majority of the studies $(n=19)$ utilized climate projections from the Special Report on Emissions Scenarios (SRES) [52], while others either utilized representative concentration pathway (RCP) scenarios $(n=11)$, which emphasize a greenhouse gas concentration (not emissions) trajectory [53], or a variety of other climate models $(n=5)$. Furthermore, 20 of the studies provided health projection estimates based upon historical infection data, while the remaining 15 studies provided infection potential estimates based upon changes in mosquito habitat. In terms of geographic focus, 10 of the studies provided global-level estimates, seven were in Asia, six in Australia, and the rest spread across the remaining continents (excluding Antarctica). Furthermore, the studies developing these future dengue case projection estimates utilized a variety of approaches that encompassed statistical, mechanistic, mathematical, and ecological models.

For the 10 studies that provided only global-level estimates for changes in future dengue case (see Table 2), the number of articles providing changes in the exposure of people to dengue due to changes in mosquito habitat vs. utilizing historical infection data in humans were evenly split (five articles each).
Studies utilizing habitat to assess changes in exposure potential provided interesting findings. For example, a study by Ryan et al. (2019) utilized multiple RCP scenarios and projected that for a worst-case scenario by the year 2080 nearly a billion people could face their first exposure to dengue due to changes in mosquito habitat, mainly in Europe and high-elevation tropical and subtropical regions. Campbell et al. (2015) supported the case for an increase in future dengue risk by utilizing SRES A1B (emphasizing rapid economic growth), A2 (emphasizing regionally oriented economic development), and B1 (emphasizing global environmental sustainability) scenarios to predict that by $2050 \mathrm{~A}$. aegypti mosquitoes could expand northward in eastern North America as well as in South and East Asia, and southward in Africa and Australia, while also broadening the distribution potential in the interior region of South America and Central Africa [54]. Similarly, Khormi et al. (2014) projected the spread of A. aegypti worldwide to contract in the strongly positive climate areas, while currently unfavorable areas, such as inland Australia, the Arabian Peninsula, southern Iran, and some parts of North America may become climatically favorable utilizing the SRES A1B and A2 scenarios. Interestingly, Messina et al. (2019) indicated similar potential expansion as the prior two studies mentioned utilizing the RCP 6.0 scenario, which is known to be similar to the SRES A1B scenario [55]. From a worst-case scenario perspective, Rogers et al. (2015) and Liu-Helmersson et al. (2014) comparatively indicated disagreements for increased numbers of dengue cases by the end of the century utilizing the similar SRES A1F1 and

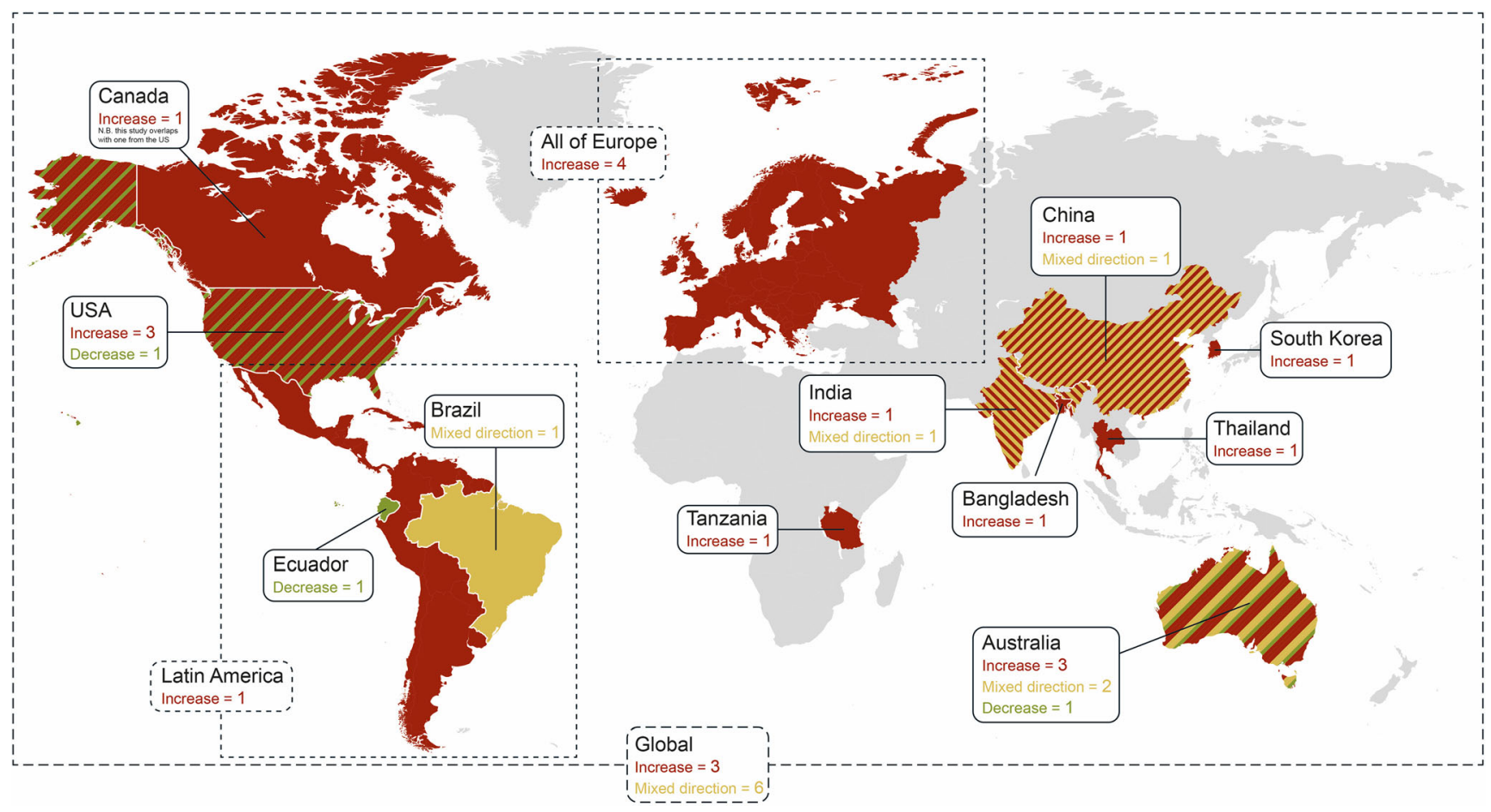

Fig. 4 Future changes in the number of dengue cases and the number of studies per country 
RCP 8.5 scenarios, respectively [55]. Proestos et al. (2015) further highlighted that direction of changes in future potential for dengue infection are geographically dependent, indicating that by the 2050s a poleward shift of the suitable habitat conditions is projected, with a significant increase in habitat suitability to occur in eastern Brazil, USA, China, and western and central Europe, while significant reductions in habitat suitability are projected for northern South America, southern Europe, central Africa, Madagascar, and Southeast Asia. Future global-level projection studies based upon infection data were also highly indicative of the geographic dependence for determining the directionality of dengue infections, with four studies projecting mixed direction and one indicating a clear increase in infections. Noteworthy, Åström et al. [56] and a 2014 report by the World Health Organization [57] indicated that economic development may have a major influence upon the distribution of future dengue risk.

Across the regions of the world, seven studies were conducted in Asia (see Table 2). Bangladesh, Korea, and Thailand each had one study, all indicating increases in dengue potential, with an increase of more than 16,000 cases projected in Dhaka by the year 2100 [58], vectorial capacity increasing by more than 2-fold in Korea by the year 2070 [59], and the transmission period increasing from five to nine months by late century in Thailand [60]. In India, two studies indicated contrasting results, with a report from the Indian government indicating a reduction in transmission by the year 2030 in the southern areas of India [61], while Dhiman et al. (2010) indicated new areas of transmission in southern areas of India by the year 2050. In neighboring China, a study conducted by Fan et al. (2019) indicated that in the 2100s, utilizing the RCP 8.5 (i.e., worst-case) scenario, the population exposed to dengue and expanded high-risk areas would increase by 4.2- and 2.9-fold, respectively. By continent, the second highest number of studies was conducted in Australia $(n=6)$. Most of these studies indicated an increase in potential transmission, with Kearney et al. (2009) demonstrating an interesting finding of increased habitat suitability throughout much of Australia by the year 2050, with changes to water storage practices in response to drought as having great influence upon this $[58,60,62]$. Only one study was found to have been conducted on the African continent. Mweya et al. (2016) illustrated that in 2020 and 2050 an intensification in dengue epidemic risk areas is anticipated with variations across Tanzania's geography.

For the European continent, four studies were found, all of which showed increase in dengue potential, with three of the four studies providing estimates for all of Europe (see Table 2). Studies were largely in agreement, with predictions by century end indicating $A$. aegypti could expand to Northern Europe under RCP 8.5 [63], along with projected increase in dengue cases, with highest incidence rates found for the 2070 2100 timeframe, with substantial impact for southern Europe
$[64,65]$. The same number of studies $(n=4)$ were found to be focused upon the North American continent, with three studies projecting an increase in dengue infection [66-68]. However, a study by Erickson et al. (2012) contrasted these findings, determining that projected warming would shorten the mosquito lifespan thus in turn decreasing the potential for the dengue season.

Lastly, in South America, studies ( $n=3$ ) were found focusing upon Brazil, Ecuador, and Latin America, all indicating a heavy geographic dependence for either the increasing or decreasing probability of contracting dengue (see Table 2). Interestingly, the study focusing on Latin America projected that during the 2050s there would be an additional 6.9 million cases per year, which represents a $260 \%$ increase relative to an average yearly number of cases taken from 1961 to 1990 [69].

Nearly a third of the studies from this review showcased global level estimates, with findings across these articles emphasizing the importance of geographical location when trying to assess future risk potential as locations will experience climate change very differently in the years to come. Similar to understanding historical risk at the local level, future level projections are also needed at a localized level so that policy makers can better evaluate how different climate-related measures will influence the chance of dengue outbreaks across their respective regions and, subsequently, concentrate resources in a more targeted and efficient manner.

\section{Discussion}

The findings for both historical dengue outbreaks as well as future projections highlight the many ways that climate change can influence the risk of contracting dengue and therefore its transmission dynamics. Understanding how different climate change variables can influence these dynamics is an important aspect of being able to further investigate these pathways as well as understand potential methods of where interventions can take place. For example, the primary vector of transmission (i.e., the mosquito) has a life cycle that can be impacted by rainfall and temperature [70]. As temperatures rise, this could increase the rate of the development of the mosquito, thereby reducing virus incubation time and resulting in the potential of increased risk of dengue transmission [71-74]. Corollary to this, extreme temperatures have the potential of reducing the mosquito's ability to survive, thus reducing the potential for transmission of dengue [75]. Precipitation can also influence the development of the vector by creating breeding habitats from standing water after rainstorms that increase transmission risk, or in contrast could result in flushing events from heavy rainfall that could wash away mosquito eggs, thus reducing the transmission potential [76]. Extreme prolonged climatic events can also drive the potential for dengue transmission by influencing human 
behavior, such as droughts that may result in people increasing water storage practices that could serve as breeding grounds for mosquitos [77]. Broader climate phenomena such as sea surface temperature or Oceanic Niño Index, can influence weather patterns (i.e., changing temperature or precipitation), and depending on the geography can further contribute towards localized impacts as mentioned, thereby altering transmission dynamics [78, 79].

\section{Future Direction of Research}

From the studies reviewed for both historical and future health risk assessment, there are several key areas of research that would benefit from additional focus moving forward. Foremost, it is clear that the impacts of climate change can vary greatly based upon locale, thus impacting the probability of contracting dengue accordingly. Conducting localized health impact assessments (and developing subsequent projections) is needed at the sub-country level so that those in the health sector can develop geographically relevant adaptation measures. Based upon the studies found, more broadly, the European continent is in need of additional research for historical risk assessments, while the African continent is in need for research related to both historical assessments and future dengue case projections. Reviewing the studies revealed limitations, a key one being that many of the historical studies are based on clinical diagnosis ( $n=16$ studies), which can be conflated with other diseases that display similar symptoms to dengue. A key area of research requiring attention stemming from this revolves around understanding how climate change impacts the four different serotypes of dengue. Additional research is needed to further understand the risk of historical incidence and future projections of contracting dengue across different serotypes, as well as how this risk changes across different demographic groups and geographic areas. In addition to the health research needed in the realm of how climate change impacts dengue, an improved understanding is also needed around the health-economic impact. Improving upon the understanding of costs associated with the diagnosis and treatment of dengue symptoms can lead to a better understanding of how interventions can benefit from both a health as well as economic lens.

\section{Addressing Knowledge Gaps}

In order to address future areas of research and strengthen the overall understanding of the climate-dengue link, there are several key actions that could serve to address these areas in a more systematic manner. These key actions cover several topics that include building human resource and data architecture capacity, integrating climate-health frameworks into national adaptation plans, and improving engagement with the public. Conducting epidemiological assessments can be a complex process and starts from having reliable data and the capacity to perform such work. Training epidemiologists that are knowledgeable in conducting climate-health risk assessments is an important step in advancing research topics in this realm. Moreover, increasing the functionality of existing data architectures can serve to augment this capacity. Specifically, integrating climate data into existing health systems, along with increasing funding to build lab capacity to conduct more detailed analysis and integrate that data accordingly, is an area that can greatly serve to further advance research on this topic. Given the rapidly changing landscape of dengue-related research, it is also recommended that tools be created to streamline the processes for creating meta-analyses (i.e., integrating health risk estimates across multiple studies for a specific region) given that many countries, particularly low- and middleincome countries, may not have the capacity to continuously assess the scientific literature for updates on risk related research that will have great implications for how they allocate future resources towards the development of adaptation measures. Another action that may serve to advance the climatehealth research agenda is to integrate frameworks similar to the US CDC's Climate-Ready States \& Cities Initiative [80] into how ministries of health approach engaging in this issue. By operating from such a framework, greater coordination and a more systematic approach can be utilized to advance research that can be translated into operational interventions. Lastly, seeking to engage the public, such as through the efforts of citizen science, can serve to enhance data sources as well as awareness of the risks and the need for collective action. For example, mobile phones in Tanzania have been utilized to identify mosquito species [81], thereby enhancing entomological data that can increase the ability of researchers to develop a more informed understanding of risk assessment.

Dengue is one of the fastest spreading infectious diseases known, and climate change is a key driver of this change. Possessing an understanding of how climate change impacts the potential for contracting dengue enables the health sector to design robust and localized adaptation measures that span high-level policy response, improved forecasting and early warning systems, resource planning and allocation for health facilities, and communicating with the public. This study provides an overview of the historical and future health risks posed by dengue from climate change and enables the research and policy community to understand where the knowledge gaps are and what areas need to be addressed in order to mitigate the health risks posed by future dengue infection.

Supplementary Information The online version contains supplementary material available at https://doi.org/10.1007/s40572-021-00322-8.

Acknowledgements This study is part of the Dengue MOdel forecasting Satellite-based System (D-MOSS) project that is funded by the UK Space 
Agency's International Partnership Programme. The consortium consists of the following partners: HR Wallingford, London School of Hygiene and Tropical Medicine, UK Met Office, Oxford Policy Management, United Nations Development Programme, World Health Organization, Vietnam Institute of Meteorology, Hydrology and Climate Change, General Department of Preventive Medicine (Ministry of Health), Pasteur Institute Ho Chi Minh City, National Institute of Hygiene and Epidemiology, Pasteur Institute Nha Trang, and Institute of Hygiene and Epidemiology Tay Nguyen.

Author Contribution Sutyajeet Soneja designed the literature search, conducted the literature search, and drafted the paper. Gina Tsarouchi assisted with designing the literature search, conducting the literature search, and drafting the paper; Darren Lumbroso assisted with designing the literature search, conducting the literature search, and drafting the paper. Dao Khanh Tung assisted with designing the literature search and drafting the paper.

Funding This study was funded by the UK Space Agency's International Partnership Programme.

Data availability All materials are included in the tables and references provided.

\section{Declarations}

Conflict of Interest The authors declare no competing interests.

Open Access This article is licensed under a Creative Commons Attribution 4.0 International License, which permits use, sharing, adaptation, distribution and reproduction in any medium or format, as long as you give appropriate credit to the original author(s) and the source, provide a link to the Creative Commons licence, and indicate if changes were made. The images or other third party material in this article are included in the article's Creative Commons licence, unless indicated otherwise in a credit line to the material. If material is not included in the article's Creative Commons licence and your intended use is not permitted by statutory regulation or exceeds the permitted use, you will need to obtain permission directly from the copyright holder. To view a copy of this licence, visit http://creativecommons.org/licenses/by/4.0/

\section{References}

1. Bhatt S, Gething PW, Brady OJ, Messina JP, Farlow AW, Moyes $\mathrm{CL}$, et al. The global distribution and burden of dengue. Nature. 2013;496(7446):504-7.

2. Simmons CP, Farrar JJ, van Vinh CN, Wills B. Dengue. N Engl J Med. 2012;366(15):1423-32.

3. World Health Organization. Dengue and severe dengue [Internet]. 2020 [cited $2020 \mathrm{Jul}$ 21]. Available from: https://www.who.int/ news-room/fact-sheets/detail/dengue-and-severe-dengue

4. Brady OJ, Gething PW, Bhatt S, Messina JP, Brownstein JS, Hoen AG, et al. Refining the global spatial limits of dengue virus transmission by evidence-based consensus. PLoS Negl Trop Dis. 2012;6(8):e1760.

5. Ebi KL, Nealon J. Dengue in a changing climate. Environ Res. 2016;151:115-23

6. Sridhar S, Luedtke A, Langevin E, Zhu M, Bonaparte M, Machabert T, et al. Effect of dengue serostatus on dengue vaccine safety and efficacy. N Engl J Med. 2018;379(4):327-40.
7. Caminade C, Medlock JM, Ducheyne E, McIntyre KM, Leach S, Baylis M, et al. Suitability of European climate for the Asian tiger mosquito Aedes albopictus: recent trends and future scenarios. J R Soc Interface. 2012;9(75):2708-17.

8. Whitehorn J, Yacoub S. Global warming and arboviral infections. Clin Med. 2019;19(2):149-52.

9. Centers for Disease Control and Prevention, National Center for Emerging and Zoonotic Infectious Diseases (NCEZID), Division of Vector-Borne Diseases (DVBD). Symptoms and treatment $\mid$ dengue | CDC [Internet]. 2020 [cited 2021 Apr 13]. Available from: https://www.cdc.gov/dengue/symptoms/index.html

10. Information NC for B, Pike USNL of M 8600 R, MD B, Usa 20894. Epidemiology, burden of disease and transmission [Internet]. Dengue: guidelines for diagnosis, treatment, prevention and control: new edition. World Health Organization; 2009 [cited 2021 Apr 13]. Available from: https://www.ncbi.nlm.nih.gov/ books/NBK143159/

11. Monath TP. Dengue: the risk to developed and developing countries. Proc Natl Acad Sci U S A. 1994;91(7):2395-400.

12. Gubler DJ. Epidemic dengue/dengue hemorrhagic fever as a public health, social and economic problem in the 21 st century. Trends Microbiol. 2002;10(2):100-3.

13. Shepard DS, Undurraga EA, Halasa YA, Stanaway JD. The global economic burden of dengue: a systematic analysis. Lancet Infect Dis. 2016;16(8):935-41.

14. Phillips ML. Dengue reborn: widespread resurgence of a resilient vector. Environ Health Perspect. 2008;116(9):A382-8.

15. Semenza JC, Sudre B, Miniota J, Rossi M, Hu W, Kossowsky D, et al. International dispersal of dengue through air travel: importation risk for Europe. PLoS Negl Trop Dis. 2014;8(12):e3278.

16. Wilder-Smith A. Dengue infections in travellers. Paediatr Int Child Health. 2012;32(Suppl 1):28-32.

17. Estallo EL, Ludueña-Almeida FF, Introini MV, Zaidenberg M, Almirón WR. Weather variability associated with Aedes (Stegomyia) aegypti (dengue vector) oviposition dynamics in Northwestern Argentina. PLOS ONE. 2015;10(5):e0127820.

18. Morin CW, Comrie AC, Ernst K. Climate and dengue transmission: evidence and implications. Environ Health Perspect. 2013;121(1112):1264-72.

19. Chan M, Johansson MA. The incubation periods of dengue viruses. PLOS ONE. 2012;7(11):e50972.

20. Barrera R, Amador M, MacKay AJ. Population dynamics of Aedes aegypti and dengue as influenced by weather and human behavior in San Juan. Puerto Rico. PLoS Negl Trop Dis. 2011;5(12):e1378.

21. Dickerson CZ. The effects of temperature and humidity on the eggs of Aedes aegypti (L.) and Aedes albopictus (Skuse) in Texas [Internet]. Texas A\&M University; 2009 [cited 2020 Jul 16]. Available from: https://oaktrust.library.tamu.edu/handle/1969.1/ ETD-TAMU-2508

22. Xu L, Stige LC, Chan K-S, Zhou J, Yang J, Sang S, et al. Climate variation drives dengue dynamics. Proc Natl Acad Sci U S A. 2017;114(1):113-8

23. Shuman EK. Global climate change and infectious diseases. N Engl J Med. 2010;362(12):1061-3.

24. Field CB, Barros V, Stocker TF, Qin D, Dokken DJ, Ebi KL, et al. Managing the risks of extreme events and disasters to advance climate change adaptation - IPCC [Internet]. The Edinburgh Building, Shaftesbury Road, Cambridge CB2 8RU ENGLAND: IPCC; 2012 Jun [cited 2020 Jul 16] p. 582 pp. Available from: https://www.ipcc.ch/report/managing-the-risks-of-extreme-eventsand-disasters-to-advance-climate-change-adaptation/

25. Johansson MA, Cummings DAT, Glass GE. Multiyear climate variability and dengue - El Niño Southern oscillation, weather, and dengue incidence in Puerto Rico, Mexico, and Thailand: a longitudinal data analysis. PLoS Med [Internet]. 2009 Nov 17 [cited 2020 
Apr 13];6(11). Available from: https://www.ncbi.nlm.nih.gov/pmc/ articles/PMC2771282/

26. Lowe R, Gasparrini A, Van Meerbeeck CJ, Lippi CA, Mahon R, Trotman AR, et al. Nonlinear and delayed impacts of climate on dengue risk in Barbados: a modelling study. PLoS Med. 2018;15(7):e1002613.

27. Johansson MA, Apfeldorf KM, Dobson S, Devita J, Buczak AL, Baugher B, et al. An open challenge to advance probabilistic forecasting for dengue epidemics. Proc Natl Acad Sci. 2019;116(48): 24268-74.

28. Mordecai EA, Ryan SJ, Caldwell JM, Shah MM, LaBeaud AD. Climate change could shift disease burden from malaria to arboviruses in Africa. Lancet Planet Health. 2020;4(9):e416-23.

29. Patz JA, Martens WJ, Focks DA, Jetten TH. Dengue fever epidemic potential as projected by general circulation models of global climate change. Environ Health Perspect. 1998;106(3):147-53.

30. NIEHS. Climate Change and Human Health Literature Portal [Internet]. National Institute of Environmental Health Sciences. 2019 [cited 2020 Jul 16]. Available from: https://tools.niehs.nih. gov/cchhl/index.cfm

31. Benedum CM, Seidahmed OME, Eltahir EAB, Markuzon N. Statistical modeling of the effect of rainfall flushing on dengue transmission in Singapore. PLoS Negl Trop Dis. 2018;12(12): e0006935.

32. Wenbiao H, Archie C, Gail W, Shilu T, Kerrie M. Spatial patterns and socioecological drivers of dengue fever transmission in Queensland. Australia. Environ Health Perspect. 2012;120(2): 260-6.

33. Lover AA, Buchy P, Rachline A, Moniboth D, Huy R, Meng CY, et al. Spatial epidemiology and climatic predictors of paediatric dengue infections captured via sentinel site surveillance, Phnom Penh Cambodia 2011-2012. BMC Public Health. 2014;14:658.

34. Phung D, Nguyen HX, Nguyen HLT, Luong AM, Do CM, Tran $\mathrm{QD}$, et al. The effects of socioecological factors on variation of communicable diseases: a multiple-disease study at the national scale of Vietnam. PloS One. 2018;13(3):e0193246.

35. Brunkard JM, Cifuentes E, Rothenberg SJ. Assessing the roles of temperature, precipitation, and ENSO in dengue re-emergence on the Texas-Mexico border region. Salud Publica Mex. 2008;50(3): 227-34.

36. Wangdi K, Clements ACA, Du T, Nery SV. Spatial and temporal patterns of dengue infections in Timor-Leste, 2005-2013. Parasit Vectors. 2018;11(1):9.

37. Liyanage P, Tissera H, Sewe M, Quam M, Amarasinghe A, Palihawadana $\mathrm{P}$, et al. A spatial hierarchical analysis of the temporal influences of the El Niño-Southern oscillation and weather on dengue in Kalutara District, Sri Lanka. Int J Environ Res Public Health [Internet]. 2016 Nov [cited 2020 Apr 2];13(11). Available from: https://www.ncbi.nlm.nih.gov/pmc/articles/PMC5129297/

38. Fan J, Lin H, Wang C, Bai L, Yang S, Chu C, et al. Identifying the high-risk areas and associated meteorological factors of dengue transmission in Guangdong Province, China from 2005 to 2011. Epidemiol Infect. 2014;142(3):634-43.

39. Iguchi JA, Seposo XT, Honda Y. Meteorological factors affecting dengue incidence in Davao, Philippines. BMC Public Health. 2018;18(1):629.

40. Chang F-S, Tseng Y-T, Hsu P-S, Chen C-D, Lian I-B, Chao D-Y. Re-assess vector indices threshold as an early warning tool for predicting dengue epidemic in a dengue non-endemic country. PLoS Negl Trop Dis [Internet]. 2015 Sep 14 [cited 2020 Apr 23];9(9). Available from: https://www.ncbi.nlm.nih.gov/pmc/ articles/PMC4569482/

41. Tuladhar R, Singh A, Varma A, Choudhary DK. Climatic factors influencing dengue incidence in an epidemic area of Nepal. BMC Res Notes [Internet]. 2019 Mar 13 [cited 2020 Jul 1];12. Available from: https://www.ncbi.nlm.nih.gov/pmc/articles/PMC6417253/
42. Vu HH, Okumura J, Hashizume M, Tran DN, Yamamoto T. Regional differences in the growing incidence of dengue fever in Vietnam explained by weather variability. Trop Med Health. 2014;42(1):25-33.

43. Choi Y, Tang CS, McIver L, Hashizume M, Chan V, Abeyasinghe $\mathrm{RR}$, et al. Effects of weather factors on dengue fever incidence and implications for interventions in Cambodia. BMC Public Health. 2016;16:241.

44. Lee HS, Nguyen-Viet H, Nam VS, Lee M, Won S, Duc PP, et al. Seasonal patterns of dengue fever and associated climate factors in 4 provinces in Vietnam from 1994 to 2013. BMC Infect Dis. 2017;17(1):218

45. Phung D, Talukder MRR, Rutherford S, Chu C. A climate-based prediction model in the high-risk clusters of the Mekong Delta region, Vietnam: towards improving dengue prevention and control. Trop Med Int Health TM IH. 2016;21(10):1324-33.

46. Moreno-Banda GL, Riojas-Rodríguez H, Hurtado-Díaz M, DanisLozano R, Rothenberg SJ. Effects of climatic and social factors on dengue incidence in Mexican municipalities in the state of Veracruz. Salud Publica Mex. 2017;59(1):41-52.

47. Astuti EP, Dhewantara PW, Prasetyowati H, Ipa M, Herawati C, Hendrayana K. Paediatric dengue infection in Cirebon, Indonesia: a temporal and spatial analysis of notified dengue incidence to inform surveillance. Parasit Vectors. 2019;12(1):186.

48. Wang C, Jiang B, Fan J, Wang F, Liu Q. A study of the dengue epidemic and meteorological factors in Guangzhou, China, by using a zero-inflated Poisson regression model: Asia Pac J Public Health [Internet]. 2013 Jun 11 [cited 2020 Apr 21]; Available from: https://journals.sagepub.com/doi/10.1177/1010539513490195

49. Anno S, Imaoka K, Tadono T, Igarashi T, Sivaganesh S, Kannathasan S, et al. Space-time clustering characteristics of dengue based on ecological, socio-economic and demographic factors in northern Sri Lanka. Geospatial Health [Internet]. 2015 Nov 26 [cited 2020 Apr 3]; Available from: https://www.geospatialhealth. net/index.php/gh/article/view/376

50. Xuan LTT, Van Hau P, Thu DT, Toan DTT. Estimates of meteorological variability in association with dengue cases in a coastal city in northern Vietnam: an ecological study. Glob Health Action. 2014;7:23119.

51. Limper M, Thai KTD, Gerstenbluth I, Osterhaus ADME, Duits AJ, van Gorp ECM. Climate factors as important determinants of dengue incidence in Curaçao. Zoonoses Public Health. 2016;63(2): 129-37.

52. Nakicenovic N, et al. Special report on emissions scenarios: a special report of working group III of the Intergovernmental Panel on Climate Change [Internet]. Cambridge, U.K.: Cambridge University Press; [cited 2020 Jul 20] p. 599. Available from: $\mathrm{http}: / /$ www.grida.no/climate/ipcc/emission/index.htm

53. IPCC data distribution center glossary [Internet]. [cited 2020 Jul 20]. Available from: https://www.ipcc-data.org/guidelines/ pages/glossary/glossary_r.html

54. Campbell LP, Luther C, Moo-Llanes D, Ramsey JM, DanisLozano R, Peterson AT. Climate change influences on global distributions of dengue and chikungunya virus vectors. Philos Trans $\mathrm{R}$ Soc B Biol Sci [Internet]. 2015 Apr 5 [cited 2020 Apr 13];370(1665). Available from: https://www.ncbi.nlm.nih. gov/pmc/articles/PMC4342968/

55. U.S. Global Change Research Program. Emissions, concentrations, and temperature projections [Internet]. GlobalChange.gov. [cited $2020 \mathrm{Jul}$ 24]. Available from: https://www.globalchange.gov/ browse/multimedia/emissions-concentrations-and-temperatureprojections

56. Åström C, Rocklöv J, Hales S, Béguin A, Louis V, Sauerborn R. Potential distribution of dengue fever under scenarios of climate change and economic development. EcoHealth. 2012;9(4):448-54. 
57. World Health Organization. Quantitative risk assessment of the effects of climate change on selected causes of death, 2030s and 2050s [Internet]. World Health Organization; 2014 [cited 2020 Apr 14]. Available from: https://apps.who.int/iris/handle/10665/ 134014

58. Banu S, Hu W, Guo Y, Hurst C, Tong S. Projecting the impact of climate change on dengue transmission in Dhaka, Bangladesh. Environ Int. 2014;63:137-42.

59. Lee H, Kim JE, Lee S, Lee CH. Potential effects of climate change on dengue transmission dynamics in Korea. PLoS ONE [Internet]. 2018 Jun 28 [cited 2020 Apr 13];13(6). Available from: https:// www.ncbi.nlm.nih.gov/pmc/articles/PMC6023222/

60. Sriprom M, Chalvet-Monfray K, Chaimane T, Vongsawat K, Bicout DJ. Monthly district level risk of dengue occurrences in Sakon Nakhon Province, Thailand. Sci Total Environ. 2010;408(22):5521-8.

61. Ministry of Environment \& Forests - Government of India. India's second national communication to United Nations framework convention on climate change [Internet]. New Delhi, India: New Delhi: Ministry of Environment and Forests; 2012 [cited 2020 May 1] p. 135-9. Available from: https://www.in.undp.org/content/india/en/ home/operations/projects/closed/enabling activitiesforpreparationofindiassecondnationalcommunica.html

62. Kearney M, Porter WP, Williams C, Ritchie S, Hoffmann AA. Integrating biophysical models and evolutionary theory to predict climatic impacts on species' ranges: the dengue mosquito Aedes aegypti in Australia. Funct Ecol. 2009;23(3):528-38.

63. Liu-Helmersson J, Quam M, Wilder-Smith A, Stenlund H, Ebi K, Massad E, et al. Climate change and Aedes vectors: 21st century projections for dengue transmission in Europe. EBioMedicine. 2016;7:267-77.

64. Bouzid M, Colón-González FJ, Lung T, Lake IR, Hunter PR. Climate change and the emergence of vector-borne diseases in Europe: case study of dengue fever. BMC Public Health. 2014;14:781.

65. Thomas SM, Fischer D, Fleischmann S, Bittner T, Beierkuhnlein C. Risk assessment of dengue virus amplification in Europe based on spatio-temporal high resolution climate change projections. Erdkunde. 2011;65(2):137-50.

66. Butterworth MK, Morin CW, Comrie AC. An analysis of the potential impact of climate change on dengue transmission in the Southeastern United States. Environ Health Perspect. 2017;125(4):579-85.

67. Ogden NH, Milka R, Caminade C, Gachon P. Recent and projected future climatic suitability of North America for the Asian tiger mosquito Aedes albopictus. Parasit vectors [Internet]. 2014 Dec 2 [cited 2020 Apr 14];7. Available from: https://www.ncbi.nlm.nih. gov/pmc/articles/PMC4261747/

68. Kolivras KN. Changes in dengue risk potential in Hawaii, USA, due to climate variability and change. Clim Res. 2010;42(1):1-11.
69. Colón-González FJ, Harris I, Osborn TJ, Steiner São Bernardo C, Peres CA, Hunter PR, et al. Limiting global-mean temperature increase to $1.5-2{ }^{\circ} \mathrm{C}$ could reduce the incidence and spatial spread of dengue fever in Latin America. Proc Natl Acad Sci U S A. 2018;115(24):6243-8.

70. Shope R. Global climate change and infectious diseases. Environ Health Perspect. 1991;96:171-4.

71. McMichael AJ, Haines A. Global climate change: the potential effects on health. BMJ. 1997;315(7111):805-9.

72. Kuno G. Review of the factors modulating dengue transmission. Epidemiol Rev. 1995;17(2):321-35.

73. Focks DA, Daniels E, Haile DG, Keesling JE. A simulation model of the epidemiology of urban dengue fever: literature analysis, model development, preliminary validation, and samples of simulation results. Am J Trop Med Hyg. 1995;53(5):489-506.

74. Patz JA, Epstein PR, Burke TA, Balbus JM. Global climate change and emerging infectious diseases. JAMA. 1996;275(3):217-23.

75. Hii YL, Rocklöv J, Ng N, Tang CS, Pang FY, Sauerborn R. Climate variability and increase in intensity and magnitude of dengue incidence in Singapore. Glob health action [Internet]. 2009 Nov 11 [cited 2021 Apr 16];2. Available from: https://www.ncbi.nlm.nih. gov/pmc/articles/PMC2799326/

76. Sarfraz MS, Tripathi NK, Tipdecho T, Thongbu T, Kerdthong P, Souris M. Analyzing the spatio-temporal relationship between dengue vector larval density and land-use using factor analysis and spatial ring mapping. BMC Public Health. 2012;12(1):853.

77. Aziz AT, Dieng H, Ahmad AH, Mahyoub JA, Turkistani AM, Mesed $\mathrm{H}$, et al. Household survey of container-breeding mosquitoes and climatic factors influencing the prevalence of Aedes aegypti (Diptera: Culicidae) in Makkah City, Saudi Arabia. Asian Pac J Trop Biomed. 2012;2(11):849-57.

78. Pramanik M, Singh P, Kumar G, Ojha VP, Dhiman RC. El Niño Southern Oscillation as an early warning tool for dengue outbreak in India. BMC Public Health. 2020;20(1):1498.

79. Adde A, Roucou P, Mangeas M, Ardillon V, Desenclos J-C, Rousset D, et al. Predicting dengue fever outbreaks in French Guiana using climate indicators. PLoS Negl Trop Dis. 2016;10(4):e0004681.

80. Climate Change and Public Health - Climate-ready states and cities initiative | CDC [Internet]. 2020 [cited 2021 Apr 15]. Available from: https://www.cdc.gov/climateandhealth/climate ready.htm

81. Carrillo MA, Kroeger A, Cardenas Sanchez R, Diaz Monsalve S, Runge-Ranzinger $\mathrm{S}$. The use of mobile phones for the prevention and control of arboviral diseases: a scoping review. BMC Public Health. 2021;21(1):110.

Publisher's Note Springer Nature remains neutral with regard to jurisdictional claims in published maps and institutional affiliations. 